\title{
Transport of short-lived halocarbons to the stratosphere over the Pacific Ocean
}

\author{
Michal T. Filus ${ }^{1}$, Elliot L. Atlas ${ }^{2}$, Maria A. Navarro ${ }^{2, \dagger}$, Elena Meneguz ${ }^{3}$, David Thomson ${ }^{3}$, Matthew J. Ashfold ${ }^{4}$, \\ Lucy J. Carpenter ${ }^{5}$, Stephen J. Andrews ${ }^{5}$, and Neil R. P. Harris ${ }^{6}$ \\ ${ }^{1}$ Centre for Atmospheric Science, University of Cambridge, Cambridge, CB2 1EW, UK \\ ${ }^{2}$ Department of Atmospheric Sciences, RSMAS, University of Miami, Miami, Florida, USA \\ ${ }^{3}$ Met Office, Atmospheric Dispersion Group, FitzRoy Road, Exeter, EX1 3PB, UK \\ ${ }^{4}$ School of Environmental and Geographical Sciences, University of Nottingham Malaysia, 43500, \\ Semenyih, Selangor, Malaysia \\ ${ }^{5}$ Wolfson Atmospheric Chemistry Laboratories, Department of Chemistry, University of York, York, YO10 5DD, UK \\ ${ }^{6}$ Centre for Environmental and Agricultural Informatics, Cranfield University, Cranfield, MK43 OAL, UK \\ $\dagger$ deceased
}

Correspondence: Neil R. P. Harris (neil.harris@cranfield.ac.uk)

Received: 26 June 2018 - Discussion started: 7 September 2018

Revised: 8 August 2019 - Accepted: 10 October 2019 - Published: 31 January 2020

\begin{abstract}
The effectiveness of transport of short-lived halocarbons to the upper troposphere and lower stratosphere remains an important uncertainty in quantifying the supply of ozone-depleting substances to the stratosphere. In early 2014, a major field campaign in Guam in the western Pacific, involving UK and US research aircraft, sampled the tropical troposphere and lower stratosphere. The resulting measurements of $\mathrm{CH}_{3} \mathrm{I}, \mathrm{CHBr}_{3}$ and $\mathrm{CH}_{2} \mathrm{Br}_{2}$ are compared here with calculations from a Lagrangian model. This methodology benefits from an updated convection scheme that improves simulation of the effect of deep convective motions on particle distribution within the tropical troposphere. We find that the observed $\mathrm{CH}_{3} \mathrm{I}, \mathrm{CHBr}_{3}$ and $\mathrm{CH}_{2} \mathrm{Br}_{2}$ mixing ratios in the tropical tropopause layer (TTL) are consistent with those in the boundary layer when the new convection scheme is used to account for convective transport. More specifically, comparisons between modelled estimates and observations of short-lived $\mathrm{CH}_{3} \mathrm{I}$ indicate that the updated convection scheme is realistic up to the lower TTL but is less good at reproducing the small number of extreme convective events in the upper TTL. This study consolidates our understanding of the transport of short-lived halocarbons to the upper troposphere and lower stratosphere by using improved model calculations to confirm consistency between observations in the boundary layer, observations in the TTL and atmospheric
\end{abstract}

transport processes. Our results support recent estimates of the contribution of short-lived bromocarbons to the stratospheric bromine budget.

\section{Introduction}

The successful implementation of the Montreal Protocol with its adjustments and amendments has led to reductions in stratospheric chlorine and bromine amounts since the late 1990s (Carpenter et al., 2014). These reductions have halted the ozone decrease (Harris et al., 2015; Chipperfield et al., 2017; Steinbrecht et al., 2017) with the exception of the possible reduction in the lower stratosphere (Ball et al., 2017, 2019; Chipperfield et al., 2017). Recently, the importance of very short-lived (VSL) chlorine- and bromine-containing compounds has received a great deal of attention (e.g. Hossaini et al., 2017; Oram et al., 2017). VSLs are not controlled under the Montreal Protocol but are required in order to reconcile observed stratospheric measurements of inorganic or "active" bromine with reported anthropogenic bromine emission sources. However, VSL input into the stratosphere has remained a poorly constrained quantity (Carpenter et al., 2014), which hinders our understanding of the ongoing de- 
cline in lower stratospheric ozone and our ability to make predictions of stratospheric ozone recovery.

Three of the most important VSL halocarbons are methyl iodide, $\mathrm{CH}_{3} \mathrm{I}$; bromoform, $\mathrm{CHBr}_{3}$; and dibromomethane, $\mathrm{CH}_{2} \mathrm{Br}_{2}$. They have typical lower tropospheric lifetimes (4, 15 and $94 \mathrm{~d}$, respectively, Carpenter et al., 2014) that are shorter than tropospheric transport timescales, thus they have non-uniform tropospheric abundances. They are emitted predominantly from the oceans and result principally from natural sources (e.g. Lovelock, 1975; Moore et al., 1995; Oram and Penkett, 1994; Vogt et al., 1999; Pyle et al., 2011; Carpenter et al., 1999, 2012, 2014; Tegtmeier et al., 2013; SaizLopez et al., 2014). The short-lived bromocarbons, chiefly $\mathrm{CHBr}_{3}$ and $\mathrm{CH}_{2} \mathrm{Br}_{2}$, have been identified as the missing source for stratospheric bromine (the sum of bromine atoms in long-lived brominated organic and inorganic substances; Pfeilsticker et al., 2000; Dessens et al., 2009). The current estimate of the contribution of the short-lived bromocarbons to the active bromine $\left(\mathrm{Br}_{y}\right)$ in the stratosphere is $\sim 5(3-7) \mathrm{ppt}$ (Engel et al., 2018), which is slightly narrower than the previous range of 3-8 ppt (Liang et al., 2010, 2014; Carpenter et al., 2014; Fernandez et al., 2014; Sala et al., 2014; Tegtmeier et al., 2015; Navarro et al., 2015, 2017; Hossaini et al., 2016; Butler et al., 2018; Fiehn et al., 2017). Much of the uncertainty is linked to the contribution of $\mathrm{CHBr}_{3}$, which has both the shortest lifetime and the largest emissions of the commonly observed bromocarbons.

The transport of VSL halocarbons into the lower stratosphere is by ascent through the tropical tropopause layer (TTL) (Fueglistaler et al., 2009). An important factor influencing the loading of the VSL bromocarbons in the TTL is the strength of the convective transport from the boundary layer where the bromocarbons are emitted (Hosking et al., 2012; Yang et al., 2014; Russo et al., 2015; Hepach et al., 2015; Fuhlbrügge et al., 2016; Krzysztofiak et al., 2018). This is poorly quantified and, when taken together with the large variations in boundary layer concentrations and the uncertainties associated with the model representation of convection, limits our ability to model the bromine budget in the current and future atmosphere (Liang et al., 2010, 2014; Russo et al., 2011, 2015; Schofield et al., 2011; Aschmann and Sinnhuber, 2013; Fernandez et al., 2014; Hossaini et al., 2016; Krzysztofiak et al., 2018).

To address this and other challenges, the Natural Environment Research Council Coordinated Airborne Studies in the Tropics (NERC CAST), National Centre for Atmospheric Research Convective Transport of Active Species in the Tropics (NCAR CONTRAST) and National Aeronautics and Space Administration Airborne Tropical Tropopause Experiment (NASA ATTREX) projects were organized (Harris et al., 2017; Jensen et al., 2017; Pan et al., 2017). These projects joined forces in January-March 2014 in the American territory of Guam, in the western Pacific. Three aircraft were deployed to sample air masses at different altitudes to investigate the characteristics of air masses influenced by deep convection. This campaign produced a unique dataset of coordinated measurements for interpretative studies of transport and distribution of the chemical species, including the VSL bromocarbons (Sect. 2.1 and 2.2). The NASA ATTREX project also measured over the less convectively active eastern Pacific in January-February 2013.

The objective of this paper is to model the transport and distribution of $\mathrm{CH}_{3} \mathrm{I}, \mathrm{CHBr}_{3}$ and $\mathrm{CH}_{2} \mathrm{Br}_{2}$ in the TTL by quantifying their boundary layer and background contribution components using a Lagrangian methodology building on the approach of Ashfold et al. (2012). A new parameterization scheme of convection for the NAME trajectory model is used, with the short-lived $\mathrm{CH}_{3} \mathrm{I}$ serving as an excellent way to assess the performance of the new scheme. Briefly, the approach uses clusters of back trajectories starting at measurement points to quantify how much of $\mathrm{CH}_{3} \mathrm{I}$, $\mathrm{CHBr}_{3}$ and $\mathrm{CH}_{2} \mathrm{Br}_{2}$ in the TTL come from the boundary layer, thereby assessing the role of convection in transporting these compounds to the TTL. The calculation is completed by estimating the background component (i.e. how much of $\mathrm{CH}_{3} \mathrm{I}, \mathrm{CHBr}_{3}$ and $\mathrm{CH}_{2} \mathrm{Br}_{2}$ originate from outside the immediate boundary layer source). Section 2 presents an overview of the field campaigns; the $\mathrm{CH}_{3} \mathrm{I}, \mathrm{CHBr}_{3}$, and $\mathrm{CH}_{2} \mathrm{Br}_{2}$ measurements; and how the NAME calculations are used. In Section 3, the approach is illustrated by comparing model estimates and measurements from one ATTREX 2014 flight. This analysis is then expanded to cover measurements from all ATTREX 2014 and 2013 flights. The role of convection in transporting VSL halocarbons to the TTL is further examined in Sect. 4. Based on the modelled calculations of $\mathrm{CHBr}_{3}$ and $\mathrm{CH}_{2} \mathrm{Br}_{2}$, Section 5 discusses how much these VSL bromocarbons contribute to the bromine budget in the TTL.

\section{Methodology}

\subsection{Overview of the CAST, CONTRAST and ATTREX campaigns}

The joint CAST, CONTRAST and (the third stage of the) ATTREX campaign took place in January-March 2014, in the western Pacific. Guam $\left(13.5^{\circ} \mathrm{N}, 144.5^{\circ} \mathrm{E}\right)$ was used as a research mission centre for these three campaigns. Three aircraft were deployed to measure physical characteristics and chemical composition of tropical air masses from the earth's surface up to the stratosphere. In CAST, the Facility for Airborne Atmospheric Measurements (FAAM) BAe-146 surveyed the boundary layer and lower troposphere $(0-8 \mathrm{~km})$ to sample the convection air mass inflow, while in $\mathrm{CON}-$ TRAST the National Science Foundation - National Center for Atmospheric Research (NSF-NCAR) Gulfstream V $(\mathrm{GV})$ principally targeted the region of maximum convective outflow in the mid-troposphere and upper troposphere and sampled down to the boundary layer on occasion (1-14 km). Finally, in ATTREX, the NASA Global Hawk (GH) sam- 
pled the TTL (13-20 km) to cover air masses likely to be detrained from the higher convective outflow. For more details on these campaigns and the objectives, meteorological conditions and descriptions of individual flights, please refer to the campaign summary papers: Harris et al. (2017) (CAST), Pan et al. (2017) (CONTRAST) and Jensen et al. (2017) (ATTREX). ATTREX had four active measurement campaigns, and we also consider the second campaign, which was based in Los Angeles in January-March 2013 and which extensively sampled the eastern and central Pacific TTL in six research flights.

\subsection{Measurements of the VSL halocarbons}

Whole Air Samplers (WAS) were deployed on all three aircraft to measure VSL halocarbons. The FAAM BAe-146 and NSF-NCAR GV also used an on-board gas chromatographymass spectrometry (GC-MS) system for real-time analysis (Wang et al., 2015; Andrews et al., 2016; Pan et al., 2017), though these measurements are not used in our analysis. WAS instrumentation is well established and has been used routinely in previous deployments. The sampling and analytical procedures are capable of accessing a wide range of mixing ratios at sufficient precision, and the measurements from the three aircraft have been shown to be consistent and comparable (Schauffler et al., 1998; Park et al., 2010; Andrews et al., 2016).

The CAST VSL halocarbon measurements were made using the standard FAAM WAS canisters with $30 \mathrm{~s}$ filling time. Up to 64 samples could be collected on each flight and these were analysed in the aircraft hangar, usually within $72 \mathrm{~h}$ after collection. A total of $2 \mathrm{~L}$ of sample air were pre-concentrated using a thermal desorption unit (Markes) and analysed with GC-MS (Agilent 7890 GC, 5977 Xtr MSD). Halocarbons were quantified using a NOAA calibration gas standard. The measurement and calibration technique is further described and assessed in Andrews et al. (2013, 2016).

The ATTREX Advanced Whole Air Sampler (AWAS) consisted of 90 canisters, being fully automated and controlled from the ground. Sample collection for the AWAS samples was determined on a real-time basis depending on the flight plan altitude, geographic location, or other relevant real-time measurements. The filling time for each canister ranged from about $25 \mathrm{~s}$ at $14 \mathrm{~km}$ to $90 \mathrm{~s}$ at $18 \mathrm{~km}$. Canisters were immediately analysed in the field using a highperformance GC-MS coupled with a highly sensitive electron capture detector. The limits of detection are compounddependent and vary from a parts-per-trillion to sub-parts-pertrillion scale, set at $0.01 \mathrm{ppt}$ for $\mathrm{CHBr}_{3}, \mathrm{CH}_{2} \mathrm{Br}_{2}$ and $\mathrm{CH}_{3} \mathrm{I}$ (Navarro et al., 2015). A small artefact of $\sim 0.01-0.02 \mathrm{ppt}$ for $\mathrm{CH}_{3} \mathrm{I}$ cannot be excluded. AWAS samples collected on the GV were analysed with the same equipment. Detailed comparison of measurements from the three systems found agreement within $\sim 7 \%$ for $\mathrm{CHBr}_{3}, \sim 3 \%$ for $\mathrm{CH}_{2} \mathrm{Br}_{2}$ and $15 \%$ for $\mathrm{CH}_{3} \mathrm{I}$ (Andrews et al., 2016).

\subsection{UK Meteorological Office NAME Lagrangian particle dispersion model}

The Lagrangian particle dispersion model, NAME (Jones, et al., 2007), is used to simulate the transport of air masses in the Pacific troposphere and the TTL. Back trajectories are calculated with particles being moved through the model atmosphere using operational analyses $\left(0.235^{\circ}\right.$ latitude and $0.352^{\circ}$ longitude, i.e. $\sim 25 \mathrm{~km}$, with 31 vertical levels below $19 \mathrm{~km}$ ) calculated by the Meteorological Office's unified model at $3 \mathrm{~h}$ intervals. This is supplemented by a random walk turbulence scheme to represent dispersion by unresolved aspects of the flow (Davies et al., 2005). For this analysis, the NAME model is used with the improved convection scheme (Meneguz and Thomson, 2014), which simulates displacement of particles subject to convective motions more realistically than previously (Meneguz et al., 2019). NAME is run backward in time to determine the origin(s) of air measured at a particular location (WAS sample) along the ATTREX GH flight track.

A total of 15000 particles are released from each point along the flight track where VSL halocarbons were measured in WAS samples. To initialize the NAME model, particles are released randomly in a volume with dimensions $0.1^{\circ} \times 0.1^{\circ} \times 0.3 \mathrm{~km}$ centred on each sample. As particles are followed $12 \mathrm{~d}$ back in time, trajectories are filtered on the basis of first crossing into the boundary layer $(1 \mathrm{~km})$. Subsequently, the fraction of particles that crossed below $1 \mathrm{~km}$ is calculated for each WAS measurement point (Ashfold et al., 2012). The NAME $1 \mathrm{~km}$ fractions are indicative of the boundary layer air mass influence to the TTL. The $1 \mathrm{~km}$ boundary layer fractions are then used to quantitatively estimate the VSL halocarbon contribution to the TTL from the boundary layer, $[X]_{\mathrm{BL}}{ }_{\mathrm{C}}$ ontribution. In order to compare the measured and modelled halocarbon values, estimates of the contribution from the background troposphere,

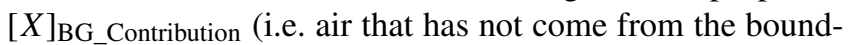
ary layer within $12 \mathrm{~d}$ ), are made. The model estimate for the total halocarbon mixing ratio, $[X]_{\mathrm{NAME} \_\mathrm{TTL}}$, is thus given by Eq. (1):

$[X]_{\mathrm{NAME}_{\mathrm{TTL}}}=[X]_{\mathrm{BL} \_ \text {Contribution }}+[X]_{\mathrm{BG} \_ \text {Contribution }}$.

The methods for calculating $[X]_{\mathrm{BL}}$ Contribution and $[X]_{B_{B} \_ \text {Contribution }}$ are now described.

\subsubsection{NAME-modelled boundary layer contribution}

The contribution from the boundary layer $\left([X]_{\mathrm{BL}}\right.$ Contribution - described above) to the VSLs in the TTL can be estimated using the following factors:

i. the fractions of trajectories crossing below $1 \mathrm{~km}$ in the previous $12 \mathrm{~d}$;

ii. the transport times to the TTL calculated for each particle; 
iii. the initial concentration values for $\mathrm{CH}_{3} \mathrm{I}, \mathrm{CHBr}_{3}$, and $\mathrm{CH}_{2} \mathrm{Br}_{2}$;

iv. their atmospheric lifetimes (to account for the photochemical removal along the trajectory).

More specifically, the boundary layer contribution to the TTL for the VSL halocarbons is calculated using Eqs. (2) and (3):

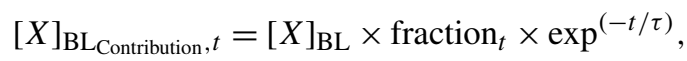

$[X]_{\mathrm{BL} \_ \text {Contribution }}=\sum\left([X]_{\mathrm{BL}}\right.$ Contribution, $\left.\mathrm{t}_{\mathrm{t}}\right)$.

Equation (2) gives the boundary layer contribution to the TTL for a given tracer, $X$ (where $X$ could be $\mathrm{CH}_{3} \mathrm{I}, \mathrm{CHBr}_{3}$, $\mathrm{CH}_{2} \mathrm{Br}_{2}$ ), at model output time step, $t$. The model output time step used is $6 \mathrm{~h}$, from $t=0$ (particle release) to $t=48$ (end of a $12 \mathrm{~d}$ run). $[X]_{\mathrm{BL}}$ stands for the initial boundary layer concentration of a given tracer - assigned to each particle that crossed below $1 \mathrm{~km}$ (Table 1). Fraction ${ }_{t}$ is a number of particles that first crossed $1 \mathrm{~km}$ in a model output time step, $t$, over a total number of particles released, and $\exp ^{(-t / \tau)}$ is a term for the photochemical loss (where $\tau$ stands for atmospheric lifetime of a respective VSL halocarbon). Equation (3) gives the boundary layer contribution that is the sum of boundary layer contribution components in all model output time steps (for $t=1$ to 48 ).

Equation (2) calculates the decay of each tracer after it leaves the boundary layer $(0-1 \mathrm{~km})$, which is valid for a wellmixed boundary layer. Since 15000 particles are released for each AWAS sample, contributions from each particle from below $1 \mathrm{~km}$ in the previous $12 \mathrm{~d}$ are summed. Decay times, $\tau$, of 4,15 and $94 \mathrm{~d}$ for $\mathrm{CH}_{3} \mathrm{I}, \mathrm{CHBr}_{3}$ and $\mathrm{CH}_{2} \mathrm{Br}_{2}$, respectively, are used (i.e. constant chemical loss rate) (Carpenter et al., 2014). Thus, a particle getting to the TTL in $1 \mathrm{~d}$ contributes more of a given tracer to that air mass than a particle taking $10 \mathrm{~d}$. Once this chemical loss term was taken into account, the NAME trajectories can be used to calculate the contribution of convection of air masses from the boundary layer within the preceding $12 \mathrm{~d}$.

The initial boundary layer concentrations are derived from the CAST and CONTRAST WAS measurements taken in the western Pacific in the same period of January-March 2014 as for the ATTREX measurements in the TTL (Table 1). These observed means are used in model calculations, and the similarity between them and literature values reported in Carpenter et al. (2014) is clear, with lower values for $\mathrm{CHBr}_{3}$ only.

\subsubsection{NAME-modelled background contribution}

To compare our model results against the AWAS observations, the background contribution, $[X]_{\text {BG_Contribution (mean- }}$ ing the contribution from the fraction of trajectories that do not cross below $1 \mathrm{~km}$ within $12 \mathrm{~d}$ ) needs to be accounted for. This requires estimates for the fraction of trajectories from

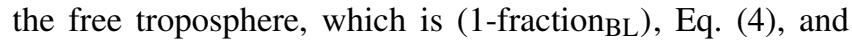
an estimate of the halocarbon mixing ratio in that fraction, $[X]_{\mathrm{BG}}$, Eq. (5), i.e. fraction $_{\mathrm{BL}}=\sum\left(\right.$ fraction $\left._{t}\right)$

$[X]_{\mathrm{BG} \_ \text {Contribution }}=\left(1-\right.$ fraction $\left._{\mathrm{BL}}.\right) \times[X]_{\mathrm{BG}}$

Since each sample has 15000 back-trajectories associated with it, some of which came from below $1 \mathrm{~km}$ and some of which did not, a definition as to which air samples are considered a boundary layer and those that are considered background is required. Two approaches are tested that use the NAME calculations to identify AWAS samples in all flights (2013 and 2014) with low convective influence by (i) filtering for air masses with boundary layer fraction values less than $1 \%, 5 \%$ or $10 \%$ or by (ii) selecting the lowest $10 \%$ of boundary layer fractions. Following this, the $\mathrm{CH}_{3} \mathrm{I}$, $\mathrm{CHBr}_{3}$ and $\mathrm{CH}_{2} \mathrm{Br}_{2}$ AWAS observations, corresponding to the boundary layer fraction values less than $1 \%, 5 \%, 10 \%$ or the lowest $10 \%$ of boundary layer fractions, are averaged to provide $\mathrm{CH}_{3} \mathrm{I}, \mathrm{CHBr}_{3}$ and $\mathrm{CH}_{2} \mathrm{Br}_{2}$ background mixing ratios. These two approaches are explored below (Sect. 3.1.2).

\subsubsection{The effect of assuming constant lifetimes}

The lifetimes of the halocarbons are not the same in the boundary layer and the TTL (Carpenter et al., 2014). The assumption of constant lifetime in a $12 \mathrm{~d}$ trajectory is evaluated by calculating the difference between idealized trajectories that had 2, 4, 6, 8 and $10 \mathrm{~d}$ in the boundary layer and 10, 8, 6, 4 and $2 \mathrm{~d}$ in the upper troposphere. Lifetimes for the boundary layer and for the upper troposphere for each gas were taken from Carpenter et al. (2014). (Lifetimes for higher altitudes are not available therein). The difference found between the two extreme cases are $6 \%\left(\mathrm{CHBr}_{3}\right), 3 \%\left(\mathrm{CH}_{2} \mathrm{Br}_{2}\right)$ and $25 \%\left(\mathrm{CH}_{3} \mathrm{I}\right)$. The assumption is thus valid for the two brominated species.

This assumption is more robust than it might seem at first glance. The boundary layer fraction is calculated using $12 \mathrm{~d}$ trajectories in which there is little loss of $\mathrm{CH}_{2} \mathrm{Br}_{2}$ whether a lifetime of 94 or $150 \mathrm{~d}$ is taken. The most important factor in determining the amount lofted into the TTL is thus the original mixing ratio, which is only slightly modulated by the chemical loss in $12 \mathrm{~d}$. The longer lifetime is absorbed implicitly and taken into account in the background contribution. The same arguments apply for $\mathrm{CHBr}_{3}$, though the effect is a bit larger. The largest difference is seen for $\mathrm{CH}_{3} \mathrm{I}$. However, the difference matters much less for $\mathrm{CH}_{3} \mathrm{I}$ because only $4 \%-5 \%$ remains after the full $12 \mathrm{~d}$, which is much smaller than the uncertainties in this analysis, so that much shorter trajectories are used to validate the new convection scheme.

\section{Analysis of ATTREX 2014 research flight 02}

We start by showing our results from a single ATTREX 2014 research flight, RF02, to illustrate the method. This is followed by analysing all research flights together for ATTREX 
Table 1. Boundary layer concentrations and atmospheric lifetimes for $\mathrm{CH}_{3} \mathrm{I}, \mathrm{CHBr}_{3}$ and $\mathrm{CH}_{2} \mathrm{Br}_{2}$ (Carpenter et.al., 2014).

\begin{tabular}{|c|c|c|c|}
\hline \multirow[t]{2}{*}{$\begin{array}{l}\text { Tracer, } \\
{[X]}\end{array}$} & \multicolumn{2}{|c|}{$\begin{array}{c}\text { Boundary layer concentration, } \\
\qquad[X]_{\mathrm{BL}}[\mathrm{ppt}]\end{array}$} & \multirow[t]{2}{*}{$\begin{array}{l}\text { Atmospheric life- } \\
\text { time, } \tau[\mathrm{d}]\end{array}$} \\
\hline & $\begin{array}{l}\text { CAST and CONTRAST } \\
\text { Mean (range) median }\end{array}$ & $\begin{array}{r}\text { Carpenter et al. (2014) } \\
\text { Median (range) }\end{array}$ & \\
\hline $\mathrm{CH}_{3} \mathrm{I}$ & $0.70(0.16-3.34) 0.65$ & $0.8(0.3-2.1)$ & 4 \\
\hline $\mathrm{CHBr}_{3}$ & $0.83(0.41-2.56) 0.73$ & $1.6(0.5-2.4)$ & 15 \\
\hline $\mathrm{CH}_{2} \mathrm{Br}_{2}$ & $0.90(0.61-1.38) 0.86$ & $1.1(0.7-1.5)$ & 94 \\
\hline
\end{tabular}

2014 and 2013 in Sect. 4 and calculating the modelled contribution of active bromine from $\mathrm{CHBr}_{3}$ and $\mathrm{CH}_{2} \mathrm{Br}_{2}$ to the TTL (Sect. 5).

\subsection{Individual ATTREX 2014 flight: research flight 02}

Figure 1 shows the vertical distribution of $\mathrm{CH}_{3} \mathrm{I}, \mathrm{CHBr}_{3}$ and $\mathrm{CH}_{2} \mathrm{Br}_{2}$ in the TTL observed during research flight, RF02, during ATTREX 2014 (Table 4). Held on 16-17 February 2014, RF02 was conducted in a confined area east of Guam $\left(12-14^{\circ} \mathrm{N}, 145-147^{\circ} \mathrm{E}\right)$ due to a faulty primary satellite communications system for Global Hawk command and control (Jensen et al., 2017). A total of 26 vertical profiles through TTL were made, with 86 AWAS measurements taken in total. A high degree of variability of $\mathrm{CH}_{3} \mathrm{I}$ in the TTL was observed (from $>0.4 \mathrm{ppt}$ at $14-15 \mathrm{~km}$, to near-zero ppt values at $17-18 \mathrm{~km}$ ). Each profile, in general, showed a gradation in $\mathrm{CH}_{3} \mathrm{I}$ distribution in the TTL. Higher values were measured in the lower TTL up to $16 \mathrm{~km}$, with values decreasing with altitude. The same pattern was observed for $\mathrm{CHBr}_{3}$ and $\mathrm{CH}_{2} \mathrm{Br}_{2}$, with the highest concentrations measured in the lower TTL (14-15 km) and the lowest at $17-18 \mathrm{~km}$.

\subsubsection{NAME-modelled boundary layer contribution}

Figure 2a shows the vertical distribution of the boundary layer air contribution to the TTL (corresponding to the AWAS measurement locations along the RF02 flight track). It reveals higher boundary layer air influence in the lower TTL, decreasing with altitude (similar to the VSL halocarbon observations). Cumulatively, the highest fractions from below $1 \mathrm{~km}$ are found for the lower TTL $(14-15 \mathrm{~km})$. A noticeable decrease occurs between the lower and upper TTL $(15$ to $17 \mathrm{~km})$. From $16 \mathrm{~km}$ up, little influence (indicated by $<10 \%$ and $<5 \% 1 \mathrm{~km}$ fractions of trajectories below $1 \mathrm{~km}$ for $16-17$ and $17-18 \mathrm{~km}$, respectively) of the low-level air masses is seen.

Figure $2 \mathrm{~b}$ shows all NAME runs for RF02 grouped into four $1 \mathrm{~km}$ TTL bins: $14-15,15-16,16-17$ and $17-18 \mathrm{~km}$. In the $14-15 \mathrm{~km}$ bin, most particles from the low troposphere arrived in the preceding $4 \mathrm{~d}$ with many in the preceding $2 \mathrm{~d}$. This represents the fast vertical uplift of the low tropospheric air masses to the lower TTL. At $15-16 \mathrm{~km}$, two particle populations are observed: the first group results from recent ver- tical uplift, while the second group has been in the upper troposphere for longer than a couple of days (see Fig. 2c in Navarro et al., 2015, for a similar example). Above $16 \mathrm{~km}$, the overwhelming majority $(>90 \%)$ of the released particles are calculated to be in the TTL for the previous $12 \mathrm{~d}$, with negligible evidence for transport from the low troposphere. This shows the dominance of the long-range, horizontal transport for the 16-17 and 17-18 km NAME runs (also shown in Navarro et al., 2015).

Figure 3 shows the locations at which trajectories crossed $1 \mathrm{~km}$, thereby indicating boundary layer source regions for the RF02 TTL air masses. Boundary layer sources in the western and central Pacific are the most important for the lowest TTL bin (14-15 km, Fig. 3a) in this flight. The Maritime Continent, the northern Australian coast, the Indian Ocean and the equatorial band of the African continent increase in relative importance as altitude increases, though the overall contribution of recent boundary layer air masses decreases with increasing altitude.

Figure 4 shows the NAME-modelled boundary layer contribution to the TTL for $\mathrm{CH}_{3} \mathrm{I}, \mathrm{CHBr}_{3}$ and $\mathrm{CH}_{2} \mathrm{Br}_{2}$ during RF02. It is important to note that this contribution corresponds to uplift from below $1 \mathrm{~km}$ in the preceding $12 \mathrm{~d}$, i.e. the length of the trajectories. The calculated boundary layer contributions for $\mathrm{CH}_{3} \mathrm{I}, \mathrm{CHBr}_{3}$ and $\mathrm{CH}_{2} \mathrm{Br}_{2}$ from the $1 \mathrm{~km}$ fractions are highest at $14-15 \mathrm{~km}$, dropping off with altitude. Almost no boundary layer contribution is found for 17$18 \mathrm{~km}$ (with values close to $0 \mathrm{ppt}$ ).

\subsubsection{NAME-modelled background contribution}

Here we explore the two approaches summarized in Sect. 2.3.2 for estimating the $\mathrm{CHBr}_{3}$ and $\mathrm{CH}_{2} \mathrm{Br}_{2}$ background mixing ratios. Similar values are seen in ATTREX 2013 and 2014. Less variation is observed for $\mathrm{CH}_{2} \mathrm{Br}_{2}$ due to its longer atmospheric lifetime.

ATTREX 2013 and 2014 are treated separately in the analysis presented below due to the difference in $\mathrm{CH}_{3} \mathrm{I}$ background estimates. The approach using the lowest $10 \%$ of the boundary layer fractions is used to estimate the background contribution for the 2014 flights as not enough data meet the former condition due to the proximity of the flights to strong convection. The background values, inferred from all the AT- 

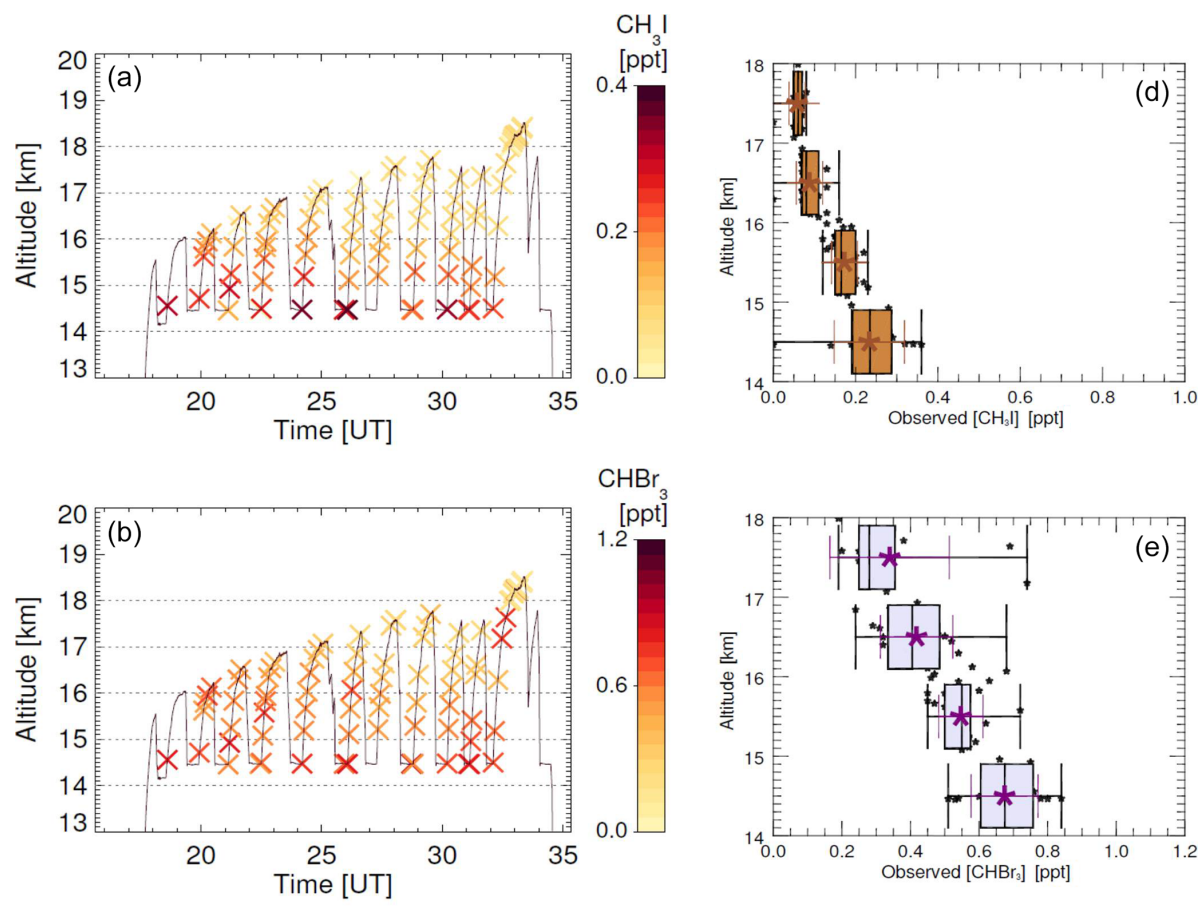

$\mathrm{CHBr}_{3}$
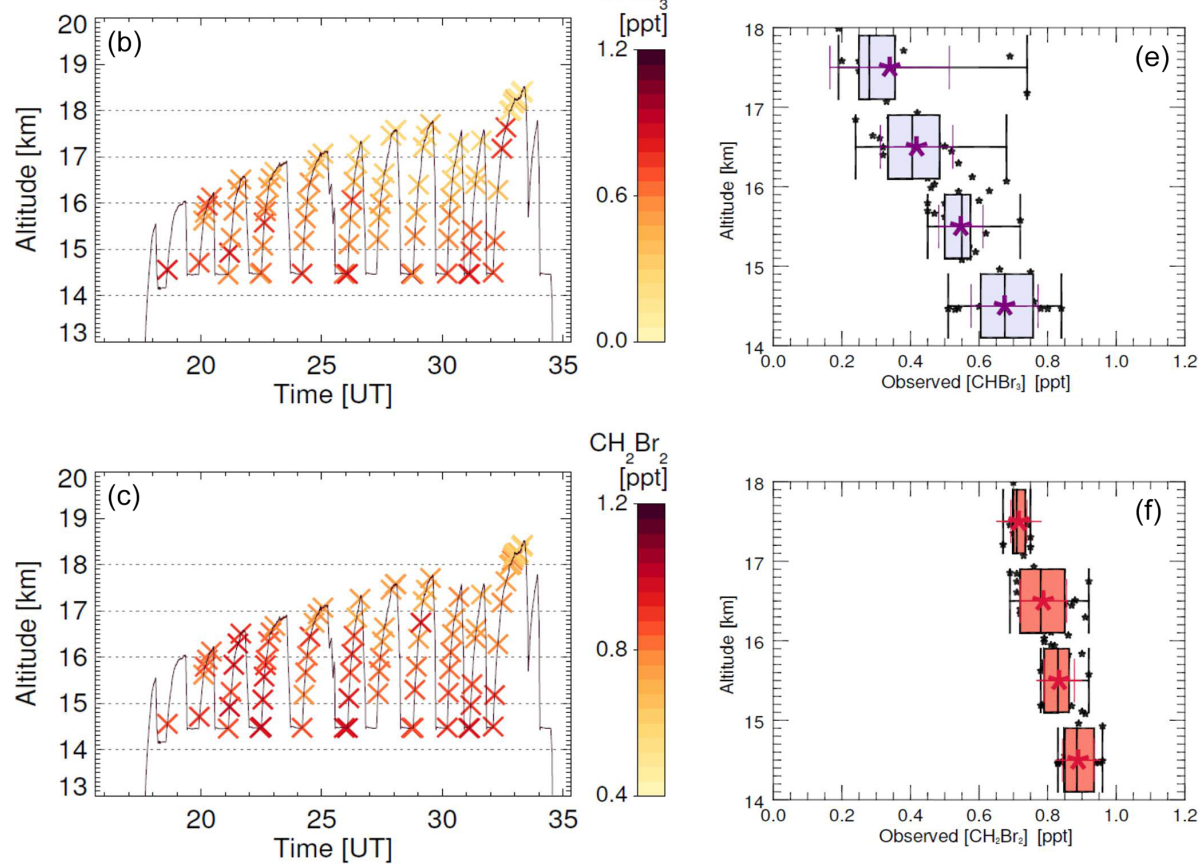

$\mathrm{CH}_{2} \mathrm{Br}_{2}$
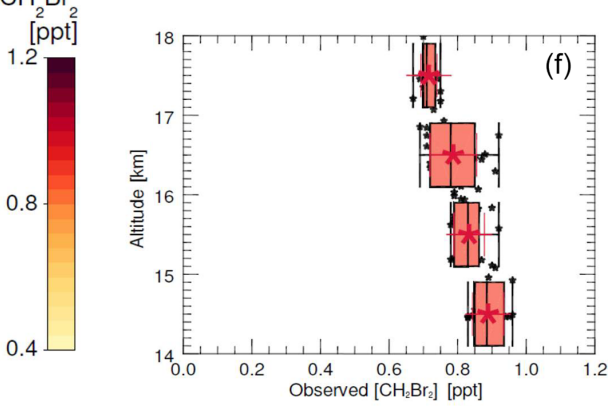

Figure 1. Vertical distribution of $\mathrm{CH}_{3} \mathrm{I}, \mathrm{CHBr}_{3}$ and $\mathrm{CH}_{2} \mathrm{Br}_{2}$ in the TTL, as measured during research flight 02, ATTREX 2014. AWAS measurements along the flight track (a-b) and observations grouped into $1 \mathrm{~km}$ TTL segments (d-f): mean (star symbols), standard deviation (coloured whiskers), minimum, lower and upper quartiles, median, and maximum (black box and whiskers).
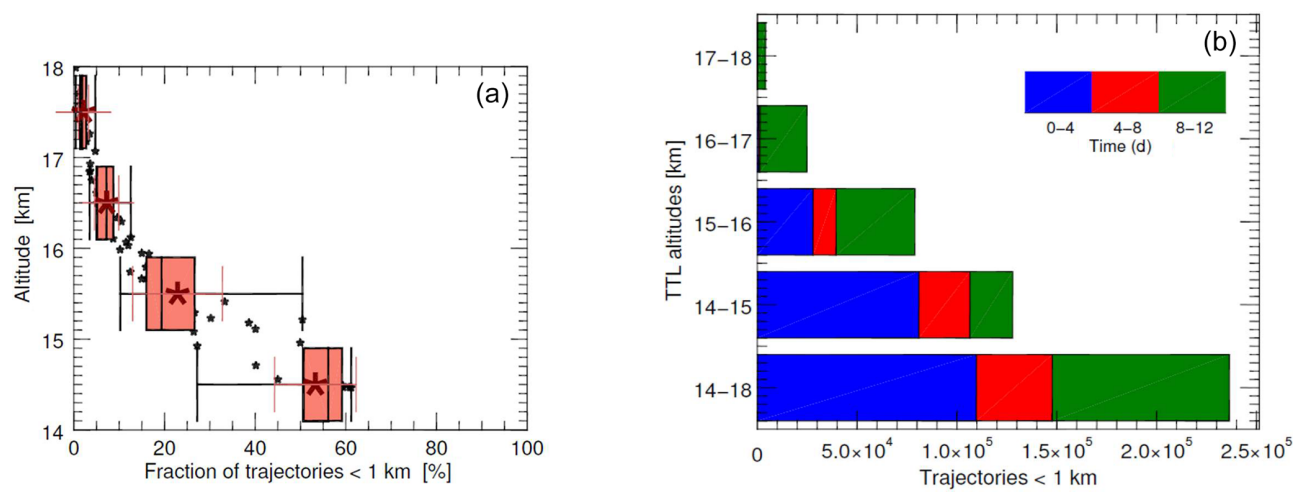

Figure 2. Vertical distribution of NAME $1 \mathrm{~km}$ fractions (the fractions that reach the boundary layer within $12 \mathrm{~d}$ - indicative of boundary layer air influence) in the TTL (a). Distribution of transport times taken for the trajectories to first cross below $1 \mathrm{~km}$ (reach the boundary layer) for all the NAME runs and the NAME runs grouped into $1 \mathrm{~km}$ TTL segments, research flight 02, ATTREX 2014 (b). 

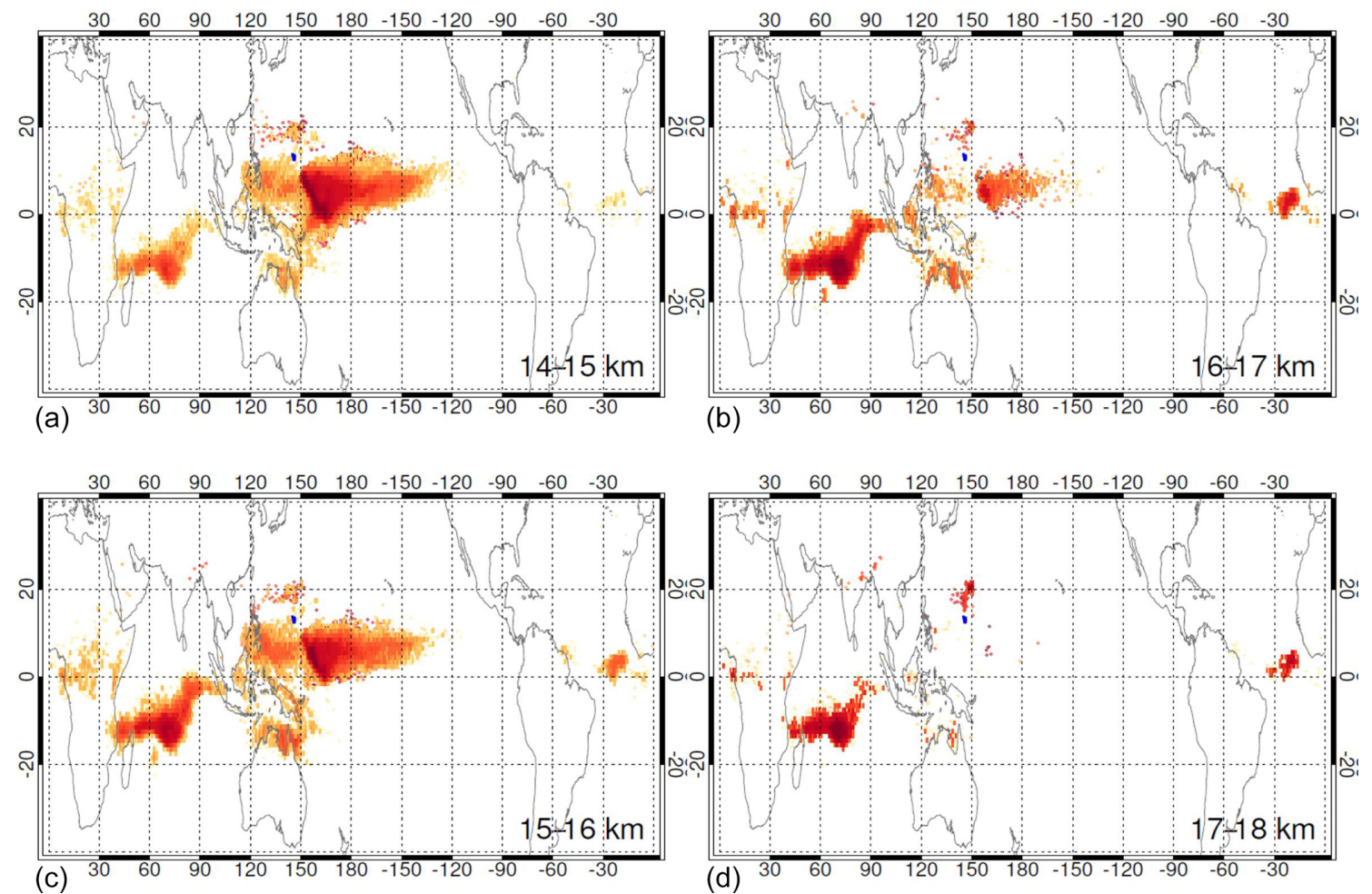

Figure 3. Crossing location distribution maps for all the NAME runs released from four $1 \mathrm{~km}$ TTL altitudes between 14 and $18 \mathrm{~km}$. Strong influence of local boundary air is noted for a 14-15 km segment (lower TTL), whereas the boundary air from remote locations dominates for a 17-18 km segment (upper TTL), research flight 02, ATTREX 2014.
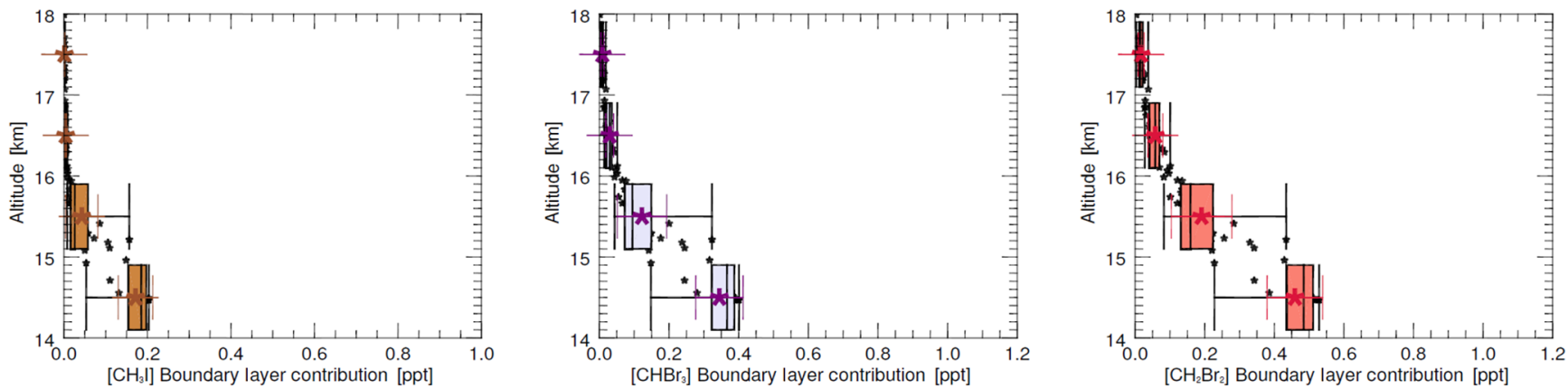

Figure 4. NAME-modelled $\mathrm{CH}_{3} \mathrm{I}, \mathrm{CHBr}_{3}$ and $\mathrm{CH}_{2} \mathrm{Br}_{2}$ boundary layer contribution to the TTL, research flight 02, ATTREX 2014.

TREX 2014 flights, are used in the individual flight calculations as again there are not enough data from an individual flight to make background calculations for that flight. In ATTREX 2013 we use the boundary layer fractions less than $5 \%$ approach for the $\mathrm{CH}_{3} \mathrm{I}$ background estimation. The ATTREX 2014 background estimates should be taken as upper limits as it is hard to identify samples with no convective influence in 2014. This is especially true for the lower TTL since the ATTREX 2014 flights were close to the region of strong convection.

Figure 5 shows the VSL background mixing ratios calculated for the ATTREX campaigns in 2013 and 2014. In AT-
TREX 2013, low $\mathrm{CH}_{3} \mathrm{I}$ background mixing ratios are found. All approaches show similar background mixing ratios. In 2014, higher $\mathrm{CH}_{3} \mathrm{I}$ background mixing ratios are calculated due to ubiquity of air from recent, vertical uplift. No boundary layer fractions less than $1 \%$ are found for the $14-17 \mathrm{~km}$ bins and none less than $5 \%$ are found for the $14-15 \mathrm{~km}$ bins.

\subsubsection{NAME-modelled total concentrations}

The NAME boundary layer and background contribution estimates are added to give an estimate for total halocarbon mixing ratio, $[X]_{\text {NAME TTL }}$, (Eq. 1 ), for comparison with the AWAS observations. 

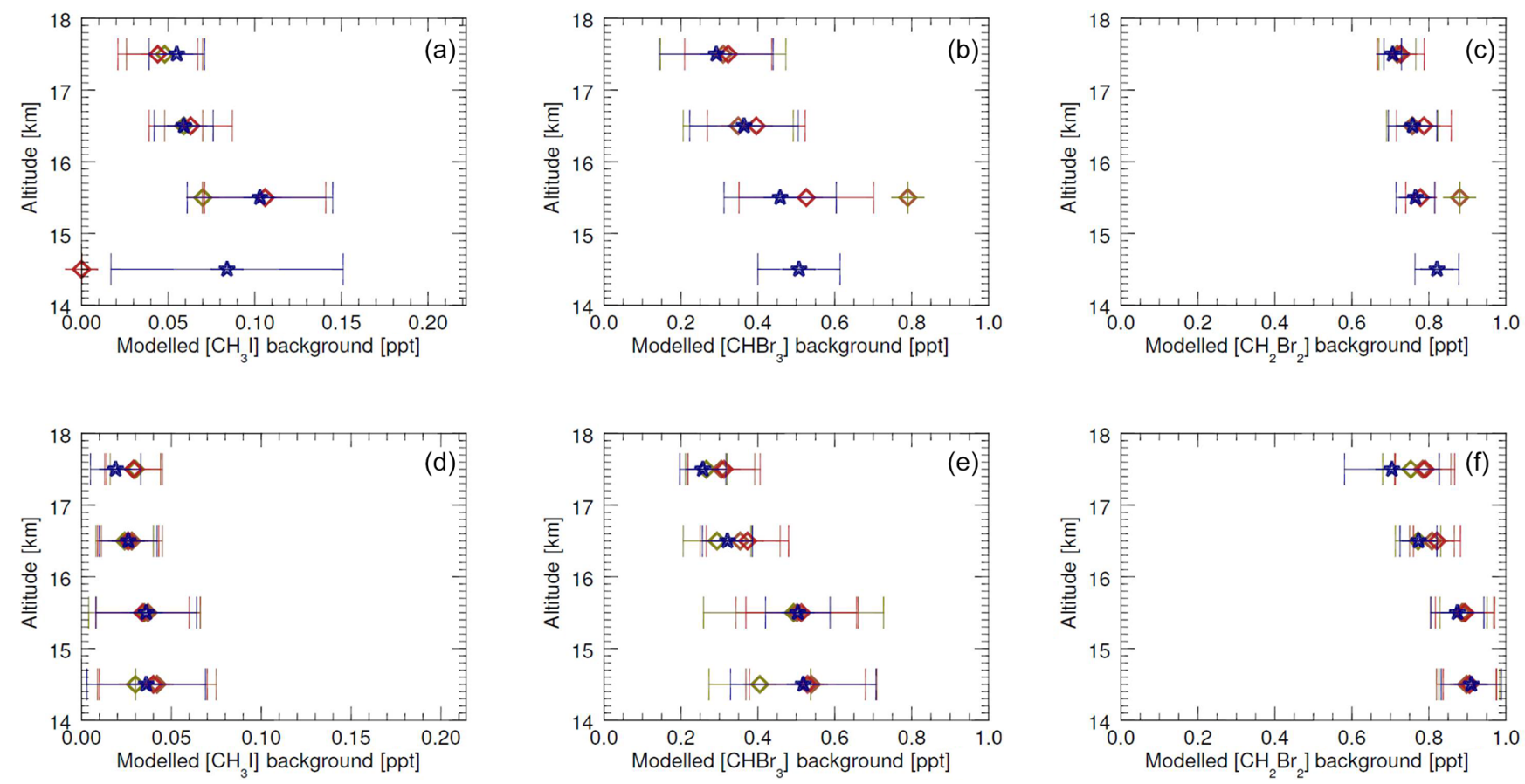

Figure 5. Background mixing ratios for $\mathrm{CH}_{3} \mathrm{I}, \mathrm{CHBr} 3$ and $\mathrm{CH}_{2} \mathrm{Br}_{2}$ for all NAME runs for all flights in ATTREX 2014 (a-c) and ATTREX 2013 (a-f). Little convective influence is indicated by selecting means from NAME $1 \mathrm{~km}$ fractions of $<1$ (blue star), 5 (red diamond) and $10 \%$ (green diamond).

Figure 6 and Table 2 show the vertical distribution of NAME-based estimates for $\mathrm{CH}_{3} \mathrm{I}, \mathrm{CHBr}_{3}$ and $\mathrm{CH}_{2} \mathrm{Br}_{2}$ in the TTL for RF02. The sums of the NAME $\mathrm{CH}_{3} \mathrm{I}, \mathrm{CHBr}_{3}$ and $\mathrm{CH}_{2} \mathrm{Br}_{2}$ boundary layer and background contribution estimates agree well with the AWAS observations for all the $1 \mathrm{~km}$ TTL bins (compared with Fig. 1).

At $14-15 \mathrm{~km}$, the modelled boundary layer contribution of $\mathrm{CH}_{3} \mathrm{I}$ is similar to the observations, indicating recent, rapid convective uplift. This provides evidence that the improved convection scheme provides a realistic representation of particle displacement via deep convection. At higher altitudes, the background contribution is more important and, indeed, the modelled total $\mathrm{CH}_{3} \mathrm{I}$ values are greater than the observations. This overestimate of the background contribution results from the difficulty of identifying samples with no convective influence in ATTREX 2014. This problem is most important for $\mathrm{CH}_{3} \mathrm{I}$ with its very short lifetime.

$\mathrm{CHBr}_{3}$ drops off slower with altitude than $\mathrm{CH}_{3} \mathrm{I}$ and quicker than $\mathrm{CH}_{2} \mathrm{Br}_{2}$. At $14-15 \mathrm{~km}$, the boundary layer contribution accounts for $\sim 50 \%$ of the modelled sums of $\mathrm{CHBr}_{3}$ and $\mathrm{CH}_{2} \mathrm{Br}_{2}$ but less than $5 \%$ for $\mathrm{CHBr}_{3}$ and $\mathrm{CH}_{2} \mathrm{Br}_{2}$ at $17-18 \mathrm{~km}$. For the upper TTL, the background contribution estimates constitute over $85 \%$ of the modelled sums, thus taking on more importance.

\section{The role of transport in the VSL halocarbon distribution in the TTL}

The role of transport in the $\mathrm{CH}_{3} \mathrm{I}, \mathrm{CHBr}_{3}$ and $\mathrm{CH}_{2} \mathrm{Br}_{2}$ distribution in the TTL is examined in this section by applying the NAME-based analysis introduced in Sect. 3 to all $\mathrm{CH}_{3} \mathrm{I}, \mathrm{CHBr}_{3}$ and $\mathrm{CH}_{2} \mathrm{Br}_{2}$ AWAS observations in the ATTREX 2013 and 2014 campaigns.

In ATTREX 2013, six flights surveyed the eastern Pacific TTL in February-March 2013. Four flights went west from Dryden Flight Research Centre to the area south of Hawaii, reaching $180^{\circ}$ longitude. Little influence of convective activity was observed. Most samples with strong boundary layer influence were observed in air masses that had originated over the western Pacific and the Maritime Continent, where it was uplifted to the TTL and transported horizontally within the TTL (Navarro et al., 2015). Two flights sampled the TTL near the Central American and South American coasts. Few convective episodes were observed. The sampled air predominantly had a small boundary layer air signature from the western Pacific and the Maritime Continent.

In ATTREX 2014, two transit flights and six research flights were made in the western Pacific in JanuaryFebruary 2014. This period coincided with the active phase of the Madden-Julian Oscillation (MJO) and increased activity of tropical cyclones. A large influence of recent convective events is observed (Navarro et al., 2015), reflected in the elevated $\mathrm{CH}_{3} \mathrm{I}$ and $\mathrm{CHBr}_{3}$ mixing ratios and the high values 

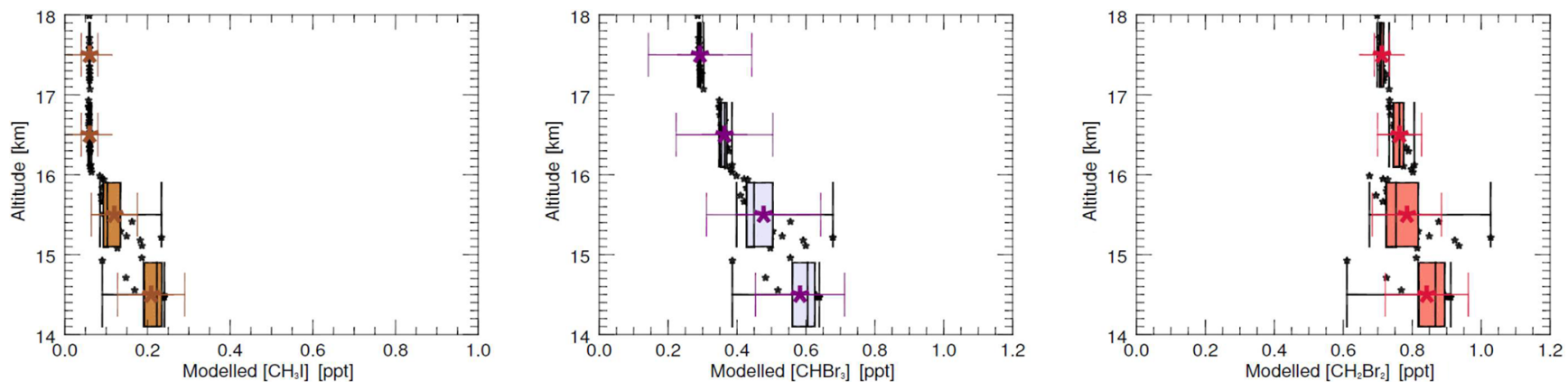

Figure 6. Vertical distribution of NAME-modelled $\mathrm{CH}_{3} \mathrm{I}, \mathrm{CHBr}_{3}$ and $\mathrm{CH}_{2} \mathrm{Br}_{2}$ (sums of boundary layer and background contribution) in the TTL for research flight 02, ATTREX 2014.

Table 2. ATTREX 2014 research flight 02. AWAS observations; modelled boundary layer contribution; and the modelled total mixing ratios for $\mathrm{CH}_{3} \mathrm{I}, \mathrm{CHBr}_{3}$, and $\mathrm{CH}_{2} \mathrm{Br}_{2}$. The boundary layer and background fraction means and standard deviations (in brackets) are given based on the measurements and modelled values for the samples collected during the flight.

\begin{tabular}{|c|c|c|c|}
\hline $\begin{array}{l}\text { Altitude } \\
{[\mathrm{km}]}\end{array}$ & $\begin{array}{l}\text { AWAS } \\
{[\mathrm{ppt}]}\end{array}$ & $\begin{array}{r}\text { Modelled boundary } \\
\text { layer contribution } \\
\text { [ppt] }\end{array}$ & $\begin{array}{r}\text { Modelled total } \\
\text { mixing ratio } \\
{[\mathrm{ppt}]}\end{array}$ \\
\hline \multicolumn{4}{|l|}{$\mathrm{CH}_{3} \mathrm{I}$} \\
\hline $17-18$ & $0.06(0.02)$ & $0.00(0.00)$ & $0.06(0.02)$ \\
\hline $16-17$ & $0.09(0.03)$ & $0.00(0.00)$ & $0.06(0.02)$ \\
\hline $15-16$ & $0.17(0.03)$ & $0.04(0.04)$ & $0.12(0.06)$ \\
\hline $14-15$ & $0.23(0.09)$ & $0.17(0.04)$ & $0.21(0.08)$ \\
\hline \multicolumn{4}{|l|}{$\mathrm{CHBr}_{3}$} \\
\hline $17-18$ & $0.34(0.17)$ & $0.01(0.00)$ & $0.29(0.15)$ \\
\hline $16-17$ & $0.42(0.11)$ & $0.03(0.01)$ & $0.36(0.14)$ \\
\hline $15-16$ & $0.55(0.06)$ & $0.12(0.07)$ & $0.48(0.17)$ \\
\hline $14-15$ & $0.67(0.10)$ & $0.35(0.07)$ & $0.58(0.13)$ \\
\hline \multicolumn{4}{|l|}{$\mathrm{CH}_{2} \mathrm{Br}_{2}$} \\
\hline $17-18$ & $0.72(0.02)$ & $0.02(0.01)$ & $0.71(0.03)$ \\
\hline $16-17$ & $0.79(0.07)$ & $0.06(0.02)$ & $0.76(0.06)$ \\
\hline $15-16$ & $0.83(0.05)$ & $0.19(0.09)$ & $0.78(0.10)$ \\
\hline $14-15$ & $0.89(0.05)$ & $0.46(0.08)$ & $0.84(0.12)$ \\
\hline & \multicolumn{2}{|c|}{$\begin{array}{c}\text { Boundary layer } \\
\text { fraction [\%] }\end{array}$} & $\begin{array}{l}\text { Background } \\
\text { fraction [\%] }\end{array}$ \\
\hline $17-18$ & \multicolumn{2}{|r|}{$2.1(1.1)$} & 97.9 \\
\hline $16-17$ & \multicolumn{2}{|r|}{$7.2(2.7)$} & 92.8 \\
\hline $15-16$ & \multicolumn{2}{|c|}{$22.9(10.0)$} & 77.1 \\
\hline $14-15$ & \multicolumn{2}{|r|}{$53.3(9.0)$} & 46.7 \\
\hline
\end{tabular}

of NAME fractions of trajectories below $1 \mathrm{~km}$. All three aircraft flew together in 2014, thus there is a more complete set of measurements from the ground up. Accordingly, this year is discussed first.

\subsection{VSL halocarbon distribution in the TTL: ATTREX 2014}

Figure 7 shows the vertical distribution of the observations and of the modelled boundary layer contribution and total mixing ratios for $\mathrm{CH}_{3} \mathrm{I}, \mathrm{CHBr}_{3}$ and $\mathrm{CH}_{2} \mathrm{Br}_{2}$ for all the ATTREX 2014 flights (using only the AWAS measurements made from $20^{\circ} \mathrm{N}$ southward). As in $\mathrm{RF} 02, \mathrm{CH}_{3} \mathrm{I}$ is highest in the lower TTL, dropping off with altitude. Large flightto-flight variability in $\mathrm{CH}_{3} \mathrm{I}$ measurements is seen. The fraction of NAME particles that travel below $1 \mathrm{~km}$ in the previous $12 \mathrm{~d}$ (Table 3 ) are highest at $14-15 \mathrm{~km}$ (mean of $57 \%$ ) and decrease with altitude in a similar fashion. The $\mathrm{CH}_{3} \mathrm{I}$ boundary layer contribution explains most of the observations for the 14-15 and 15-16 km layers. Disparities in observed and modelled $\mathrm{CH}_{3} \mathrm{I}$ arise from $16 \mathrm{~km}$ upwards. Estimated background values are very low, oscillating between 0 and the limit of detection of the AWAS instrument for the iodinated short-lived organic substances, $0.01 \mathrm{ppt}$. The sums of the $\mathrm{CH}_{3} \mathrm{I}$ boundary layer and background contribution estimates show good agreement with AWAS observations for all the TTL $1 \mathrm{~km}$ segments (Table 3 ).

The good agreement for the 14-15 and 15-16 km layers can be attributed to the improved representation of deep convection in NAME, provided by the new convection scheme (Meneguz et al., 2019). However, there is an underestimation of the boundary layer contribution to the upper TTL levels (16-17 and 17-18 km), which we attribute to the new convection scheme not working as well at these altitudes. This is consistent with a known tendency of the unified model to underestimate the depth of deepest convection in the tropics (Walters et al., 2019). Both the $\mathrm{CH}_{3}$ I AWAS observations and the modelled sums are higher than reported previously in the literature (Carpenter et al., 2014) for all the TTL segments. This may be explained by sampling the TTL in a region of 

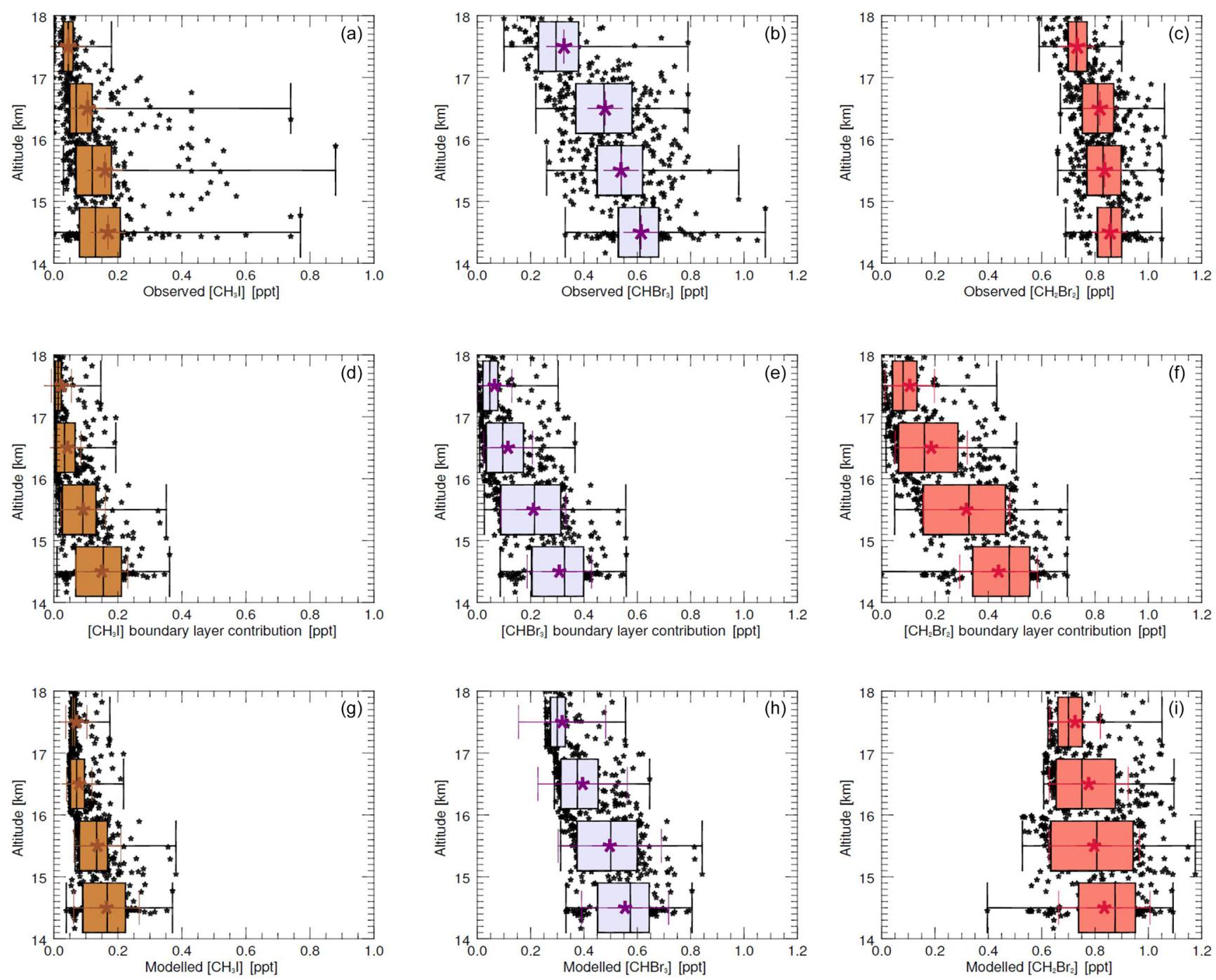

Figure 7. $\mathrm{CH}_{3} \mathrm{I}, \mathrm{CHBr}_{3}$ and $\mathrm{CH}_{2} \mathrm{Br}_{2}$ vertical distribution in the TTL for ATTREX 2014 flights.: AWAS observations (a-c), NAME-modelled boundary layer contribution (d-f), and NAME-modelled sums of boundary layer and background contributions (g-i).

high convective activity. This result gives confidence in the quality of the new convection scheme and hence in similar calculations of convective influence on the longer-lived $\mathrm{CHBr}_{3}$ and $\mathrm{CH}_{2} \mathrm{Br}_{2}$.

The highest $\mathrm{CHBr}_{3}$ and $\mathrm{CH}_{2} \mathrm{Br}_{2}$ concentrations were observed in the lower TTL $(14-15 \mathrm{~km})$, dropping off more slowly with altitude than $\mathrm{CH}_{3} \mathrm{I}$. The weight of the modelled boundary layer contribution estimates to the modelled total amounts varies from approximately $50 \%$ at $14-15 \mathrm{~km}$ (unlike for $\mathrm{CH}_{3} \mathrm{I}$ where over $85 \%$ of the modelled sum is attributed to the boundary layer contribution at $14-15 \mathrm{~km}$ ) to $<20 \%$ at $17-18 \mathrm{~km}$. The sums of the modelled boundary layer and background contributions are in good agreement with the $\mathrm{CHBr}_{3}$ and $\mathrm{CH}_{2} \mathrm{Br}_{2}$ AWAS observations. The ATTREX observations and the NAME-modelled sums are within the range of values reported in the literature (Carpenter et al., 2014).

\subsection{VSL halocarbon distribution in the TTL: ATTREX 2013}

Figure 8 shows the vertical distribution for $\mathrm{CH}_{3} \mathrm{I}, \mathrm{CHBr}_{3}$ and $\mathrm{CH}_{2} \mathrm{Br}_{2}$ in the TTL observed and modelled from the ATTREX 2013 flights. Only AWAS measurements taken south of $20^{\circ} \mathrm{N}$ are used. Much lower $\mathrm{CH}_{3} \mathrm{I}$ values are found in 2013 than in 2014 (Fig. 7). The NAME $1 \mathrm{~km}$ fractions are considerably lower ( $\sim$-fold), and the corresponding $\mathrm{CH}_{3} \mathrm{I}$ boundary layer contribution shows values close to the limit of detection of the AWAS instrument for $\mathrm{CH}_{3} \mathrm{I}$. The background contribution comprises over $85 \%-90 \%$ of the sums of the modelled $\mathrm{CH}_{3} \mathrm{I}$ estimate in the TTL. Good agreement is found between the AWAS observations and the sum of the modelled boundary layer and background contributions. Both the observed and modelled values are in the low end of 
Table 3. ATTREX 2014 all fights. AWAS observations; modelled boundary layer contribution; and the modelled total mixing ratios for $\mathrm{CH}_{3} \mathrm{I}, \mathrm{CHBr}_{3}$, and $\mathrm{CH}_{2} \mathrm{Br}_{2}$. The boundary layer and background fractions are also given. Means and standard deviations are given in brackets.

\begin{tabular}{|c|c|c|c|}
\hline $\begin{array}{l}\text { Altitude } \\
{[\mathrm{km}]}\end{array}$ & $\begin{array}{r}\text { AWAS } \\
{[\mathrm{ppt}]}\end{array}$ & $\begin{array}{r}\text { Modelled boundary } \\
\text { layer contribution } \\
{[\mathrm{ppt}]}\end{array}$ & $\begin{array}{r}\text { Modelled total } \\
\text { mixing ratio } \\
{[\mathrm{ppt}]}\end{array}$ \\
\hline \multicolumn{4}{|l|}{$\mathrm{CH}_{3} \mathrm{I}$} \\
\hline $17-18$ & $0.04(0.03)$ & $0.02(0.03)$ & $0.07(0.04)$ \\
\hline $16-17$ & $0.11(0.10)$ & $0.04(0.04)$ & $0.09(0.05)$ \\
\hline $15-16$ & $0.16(0.14)$ & $0.09(0.07)$ & $0.15(0.08)$ \\
\hline $14-15$ & $0.17(0.14)$ & $0.15(0.08)$ & $0.19(0.11)$ \\
\hline \multicolumn{4}{|l|}{$\mathrm{CHBr}_{3}$} \\
\hline $17-18$ & $0.33(0.14)$ & $0.06(0.06)$ & $0.32(0.16)$ \\
\hline $16-17$ & $0.48(0.13)$ & $0.12(0.09)$ & $0.40(0.17)$ \\
\hline $15-16$ & $0.54(0.13)$ & $0.21(0.12)$ & $0.50(0.19)$ \\
\hline $14-15$ & $0.61(0.13)$ & $0.31(0.12)$ & $0.55(0.16)$ \\
\hline \multicolumn{4}{|l|}{$\mathrm{CH}_{2} \mathrm{Br}_{2}$} \\
\hline $17-18$ & $0.73(0.06)$ & $0.11(0.09)$ & $0.73(0.09)$ \\
\hline $16-17$ & $0.82(0.08)$ & $0.19(0.14)$ & $0.78(0.15)$ \\
\hline $15-16$ & $0.84(0.09)$ & $0.32(0.16)$ & $0.80(0.17)$ \\
\hline \multirow[t]{2}{*}{$14-15$} & $0.86(0.07)$ & $0.44(0.15)$ & $0.84(0.17)$ \\
\hline & \multicolumn{2}{|c|}{$\begin{array}{c}\text { Boundary layer } \\
\text { fraction [\%] }\end{array}$} & $\begin{array}{l}\text { Background } \\
\text { fraction [\%] }\end{array}$ \\
\hline $17-18$ & \multicolumn{2}{|c|}{$12.7(10.9)$} & 87.3 \\
\hline $16-17$ & \multicolumn{2}{|c|}{$22.3(16.0)$} & 77.7 \\
\hline $15-16$ & \multicolumn{2}{|c|}{$37.8(18.8)$} & 62.2 \\
\hline $14-15$ & \multicolumn{2}{|c|}{$51.7(16.1)$} & 48.3 \\
\hline
\end{tabular}

the $\mathrm{CH}_{3} \mathrm{I}$ concentrations reported by the WMO 2014 Ozone Assessment (Carpenter et al., 2014).

The ATTREX 2013 mixing ratios are lower for $\mathrm{CHBr}_{3}$ and higher $\mathrm{CH}_{2} \mathrm{Br}_{2}$ than shown in Fig. 7 for 2014. The NAMEcalculated $\mathrm{CHBr}_{3}$ and $\mathrm{CH}_{2} \mathrm{Br}_{2}$ boundary layer contributions are small, constituting approximately $10 \%$ of the NAMEmodelled sums for $14-15 \mathrm{~km}$ and less for the upper TTL segments. The background contribution estimates comprise over $85 \%$ of the modelled sums. Good agreement is found between the sums of the modelled boundary layer and background contributions and the $\mathrm{CHBr}_{3}$ and $\mathrm{CH}_{2} \mathrm{Br}_{2}$ AWAS observations.

\subsection{ATTREX 2013 and 2014: inter-campaign comparison}

Clear differences in the vertical distributions of $\mathrm{CH}_{3} \mathrm{I}$ in the TTL are found in ATTREX 2013 and 2014. $\mathrm{CH}_{3} \mathrm{I}$ estimates, corresponding to high values in the NAME-modelled $1 \mathrm{~km}$ fractions, are high in 2014, whereas in 2013 almost no $\mathrm{CH}_{3} \mathrm{I}$ is estimated to be in the TTL. This is due to the minimal contribution of the boundary layer air within the previous $12 \mathrm{~d}$ :
ATTREX 2013 was in the eastern Pacific away from the main region of strong convection. Longer transport timescales result from horizontal transport and were more important in ATTREX 2013, with much less recent convective influence than in ATTREX 2014. More chemical removal of $\mathrm{CH}_{3} \mathrm{I}$ and $\mathrm{CHBr}_{3}$ thus took place, leading to lower concentrations in the eastern Pacific TTL.

The trajectories are analysed to investigate the timescales for vertical transport by calculating how long it took particles to go from below $1 \mathrm{~km}$ to the TTL. In 2013, almost no episodes of recent rapid vertical uplift are found, with most particles taking $8 \mathrm{~d}$ and more to cross the $1 \mathrm{~km}$. This is indicative of the dominant role of long-range horizontal transport. In 2014, by way of contrast, a considerable number of trajectories (tenths of a percent) come from below $1 \mathrm{~km}$ in less than $4 \mathrm{~d}$, representing the "young" air masses being brought from the low troposphere via recent and rapid vertical uplift.

The spatial variability in the boundary layer mixing ratios corresponding to different source strengths coupled with the variation in atmospheric transport pathways and transport timescales can explain the differences in the distribution of the NAME $1 \mathrm{~km}$ fractions in the TTL. In 2014 (2013), higher (lower) boundary layer fractions corresponded well with higher (lower) $\mathrm{CH}_{3} \mathrm{I}$ and $\mathrm{CHBr}_{3}$ values in the TTL, especially with the highest concentrations occurring for the flights with the most convective influence and the highest fractions of particles arriving within the $4 \mathrm{~d}$.

In 2014, the western and central Pacific is the dominant source origin of boundary layer air to the TTL (Navarro et al., 2015). Increased tropical cyclone activity in this area (particularly Faxai, 28 February-6 March 2014, and Lusi, 7-17 March 2014) and the strong signal from convection related to the Madden Julian Oscillation (MJO - an intraseasonal phenomenon characterized by an eastward spread of large regions of enhanced and suppressed tropical rainfall, mainly observed over the Indian and Pacific Ocean) contributed to the more frequent episodes of strong and rapid vertical uplifts of the low-level air to the TTL. A significant contribution is also seen from the central Indian Ocean, marking the activity of Tropical Cyclone Fobane (6-14 February 2014). Minimal contribution from the other remote sources (Indian Ocean, African continental tropical band) is found (Anderson et al., 2016; Jensen et al., 2017; Newton et al., 2018).

\section{How much do VSL bromocarbons contribute to the bromine budget in the TTL?}

The NAME-modelled $\mathrm{CHBr}_{3}$ and $\mathrm{CH}_{2} \mathrm{Br}_{2}$ estimates in the TTL are used to calculate how much bromine from the VSL

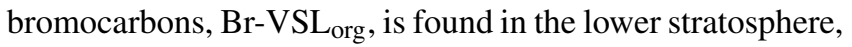
based on how much enters the TTL in the form of bromocarbons (Navarro et al., 2015). $\mathrm{CHBr}_{3}$ and $\mathrm{CH}_{2} \mathrm{Br}_{2}$ are the dominant short-lived organic bromocarbons, and the minor 

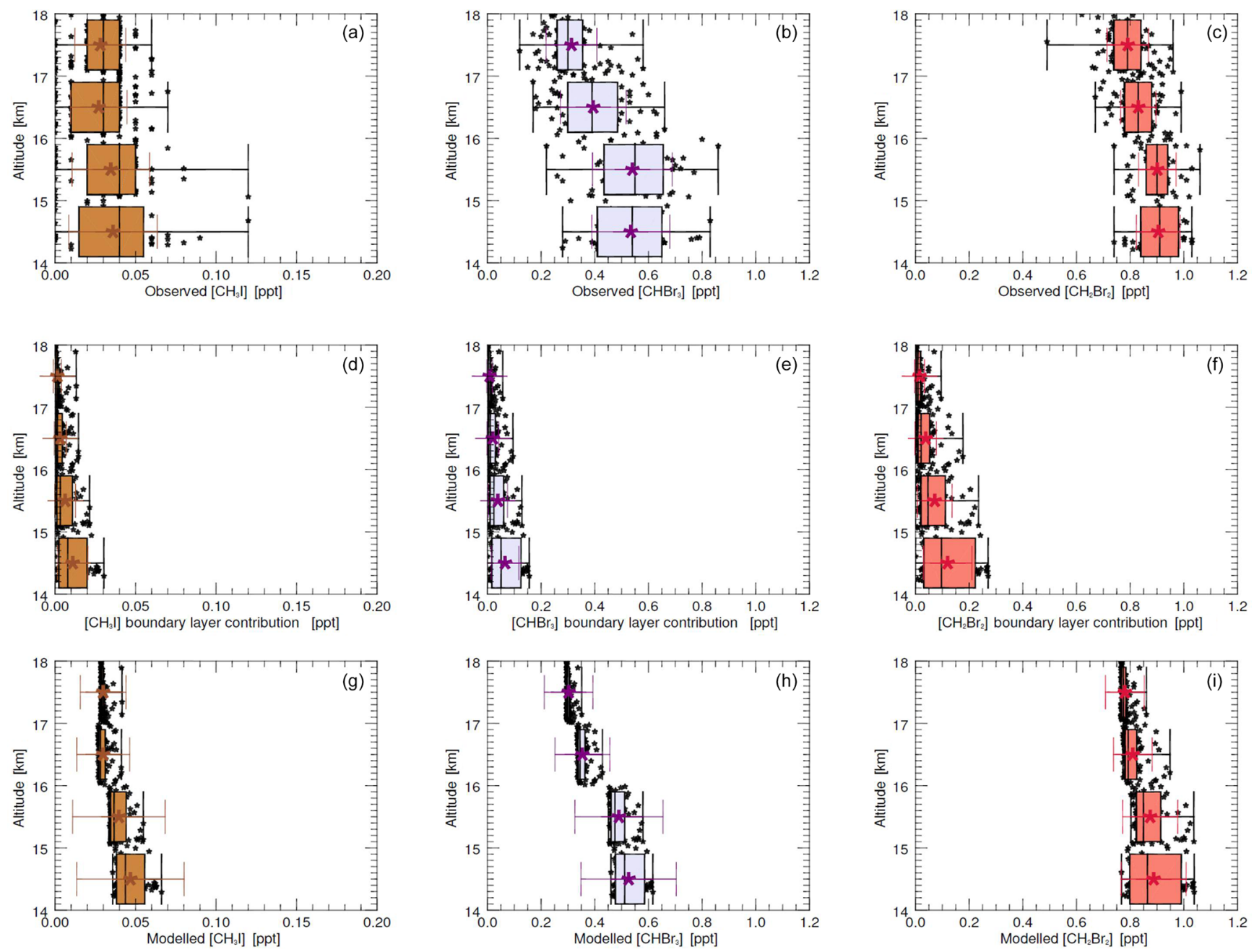

Figure 8. $\mathrm{CH}_{3} \mathrm{I}, \mathrm{CHBr}_{3}$ and $\mathrm{CH}_{2} \mathrm{Br}_{2}$ vertical distribution in the TTL for ATTREX 2013 flights: AWAS observations (a-c), NAME-modelled boundary layer contribution (d-f), and NAME-modelled sums of boundary layer and background contributions (g-i).

bromocarbons, $\mathrm{CH}_{2} \mathrm{BrCl}, \mathrm{CHBr}_{2} \mathrm{Cl}$ and $\mathrm{CHBrCl}_{2}$, are excluded here (their combined contribution is less than $1 \mathrm{ppt}$ to Br-VSL $_{\text {org }}$ at $14-18 \mathrm{~km}$, Navarro et al., 2015). The NAMEmodelled $\mathrm{CHBr}_{3}$ and $\mathrm{CH}_{2} \mathrm{Br}_{2}$ estimates are multiplied by the number of bromine atoms (bromine atomicity) and then summed to yield the total of Br-VSL $\mathrm{V}_{\text {org }}$.

Figure 9 shows the contribution of $\mathrm{CHBr}_{3}$ and $\mathrm{CH}_{2} \mathrm{Br}_{2}$, the two major VSL bromocarbons contributing to the bromine budget in the TTL. For ATTREX 2013 and 2014, similar contributions of $\mathrm{CHBr}_{3}$ and $\mathrm{CH}_{2} \mathrm{Br}_{2}$ to $\mathrm{Br}^{-\mathrm{VSL}_{\text {org }}}$ are found in the lower TTL. In 2014, $\mathrm{CHBr}_{3}$ in the lower TTL was abundant enough to contribute as much $\mathrm{Br}^{-\mathrm{VSL}_{\text {org }}}$ as $\mathrm{CH}_{2} \mathrm{Br}_{2}$. A combination of larger boundary layer air influence in the TTL and shorter mean transport times to reach the TTL result in the observed higher $\mathrm{CHBr}_{3}$ contribution to the Br-VSL ${ }_{\text {org }}$ in the lower TTL in 2014, than in 2013. The $\mathrm{CH}_{2} \mathrm{Br}_{2}$ contribution dominates in the upper TTL due to its longer atmospheric lifetime.
Good agreement is found between the bromine loading from the VSL bromocarbons, inferred from the NAMEmodelled estimates initialized with BAe-146 and GV measurements, and the Global Hawk AWAS observations. Higher organic bromine loading is seen around the cold point tropopause (16-17 km) in ATTREX 2014.

Using the upper troposphere measurements taken during the SHIVA campaign in the western Pacific in NovemberDecember 2011, Sala et al. (2014) calculated an estimate for VSL $\left(\mathrm{CHBr}_{3}, \mathrm{CH}_{2} \mathrm{Br}_{2}, \mathrm{CHBrCl}_{2}, \mathrm{CH}_{2} \mathrm{BrCl}, \mathrm{CHBr}_{2} \mathrm{Cl}\right.$ ) contributions to the organic bromine at the level of zero radiative heating $(15.0-15.6 \mathrm{~km})$. Air masses reaching this level are expected to reach the stratosphere. This VSL mean mixing ratio estimate of $2.88( \pm 0.29) \mathrm{ppt}(2.35 \mathrm{ppt}$ for $\mathrm{CHBr}_{3}$ and $\mathrm{CH}_{2} \mathrm{Br}_{2}$, excluding minor short-lived bromocarbons) is lower due to a lower contribution from $\mathrm{CHBr}_{3}$ estimate (0.22 ppt compared to the $\mathrm{CHBr}_{3}$ estimate for NAME/ATTREX in Table 5). Our estimates of the contri- 

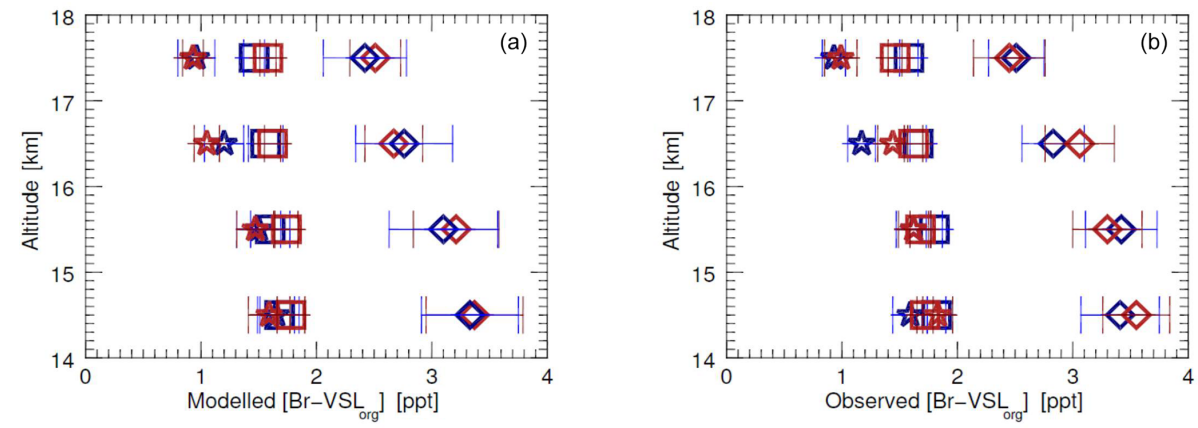

Figure 9. Contribution of $\mathrm{CHBr}_{3}$ (star symbol) and $\mathrm{CH}_{2} \mathrm{Br}_{2}$ (square symbol) to the bromine budget in the TTL, inferred from the NAMEmodelled estimates (a) and AWAS observations (b); ATTREX 2014 (red) and 2013 (blue) are shown separately. Stars and square symbols represent the bromine atomicity products from $\mathrm{CHBr}_{3}$ and $\mathrm{CH}_{2} \mathrm{Br}_{2}$, respectively. Diamonds show the bromine contribution from the VSL bromocarbons in the TTL (as a sum of the $\mathrm{CHBr}_{3}$ and $\mathrm{CH}_{2} \mathrm{Br}_{2}$ bromine atomicity products).

bution of $\mathrm{CHBr}_{3}$ and $\mathrm{CH}_{2} \mathrm{Br}_{2}$ to the organic bromine at the Level of Zero Radiative Heating (LZRH) are largely slightly higher than those in Sala et al. (2014) due to a higher estimate for a shorter-lived $\mathrm{CHBr}_{3}$.

Several papers use the same measurements from the combined ATTREX/CAST/CONTRAST campaign in 2014 and from the other ATTREX phases. Navarro et al. (2015) report slightly higher bromine loading from the Br-VSL $\mathrm{V}_{\text {org }}$ at the tropopause level $(17 \mathrm{~km})$ in the western Pacific in 2014 than in the eastern Pacific in 2013 (the Br-VSL ${ }_{\text {org }}$ values from the AWAS observations were of $3.27 \mathrm{ppt}, \pm 0.47$, and $2.96 \mathrm{ppt}, \pm 0.42$, respectively). The minor short-lived organic bromine substances were included in the analysis of Navarro et al. (2015), accounting for the higher Br-VSL $\mathrm{Vrg}_{\text {org }}$. Butler et al. (2018), report a mean mole fraction and range of $0.46(0.13-0.72)$ ppt and $0.88(0.71-1.01)$ ppt of $\mathrm{CHBr}_{3}$ and $\mathrm{CH}_{2} \mathrm{Br}_{2}$, respectively, being transported to the TTL during January and February 2014. This is consistent with a contribution of 3.14 (1.81-4.18) ppt of organic bromine to the TTL over the region of the campaign. The analysis of the injection of brominated VSLs into the TTL by Wales et al. (2018) using the CAM-chem-SD model combined with a steady-state photochemical box model and CONTRAST and ATTREX data found that $2.9 \pm 0.6 \mathrm{ppt}$ of bromine enters the stratosphere via organic source gas injection of VSLs. The NAME-modelled results presented here (Fig. 9, Table 5) are thus in good agreement with the values reported by Navarro et al. (2015), Butler et al. (2018) and Wales et al. (2018).

\section{Summary and discussion}

We have used the NAME trajectory model in backward mode to assess the contribution of recent convection to the mixing ratios of three short-lived halocarbons, $\mathrm{CH}_{3} \mathrm{I}, \mathrm{CHBr}_{3}$ and $\mathrm{CH}_{2} \mathrm{Br}_{2}$. The 15000 back-trajectories are computed for each measurement made with the whole air samples on the NASA Global Hawk in ATTREX 2013 and 2014, and the fraction
Table 4. ATTREX 2013 all flights. AWAS observations; modelled boundary layer contribution; and the modelled total mixing ratios for $\mathrm{CH}_{3} \mathrm{I}, \mathrm{CHBr}_{3}$, and $\mathrm{CH}_{2} \mathrm{Br}_{2}$. The boundary layer and background fractions are also given. Means and standard deviations are given in brackets.

\begin{tabular}{|c|c|c|c|}
\hline $\begin{array}{l}\text { Altitude } \\
{[\mathrm{km}]}\end{array}$ & $\begin{array}{r}\text { AWAS } \\
\text { [ppt] }\end{array}$ & $\begin{array}{r}\text { Modelled boundary } \\
\text { layer contribution } \\
{[\mathrm{ppt}]}\end{array}$ & $\begin{array}{r}\text { Modelled total } \\
\text { mixing ratio } \\
{[\mathrm{ppt}]}\end{array}$ \\
\hline \multicolumn{4}{|l|}{$\mathrm{CH}_{3} \mathrm{I}$} \\
\hline $17-18$ & $0.03(0.02)$ & $0.00(0.00)$ & $0.03(0.01)$ \\
\hline $16-17$ & $0.03(0.02)$ & $0.00(0.00)$ & $0.03(0.02)$ \\
\hline $15-16$ & $0.04(0.02)$ & $0.01(0.01)$ & $0.03(0.03)$ \\
\hline $14-15$ & $0.04(0.03)$ & $0.01(0.01)$ & $0.05(0.03)$ \\
\hline \multicolumn{4}{|l|}{$\mathrm{CHBr}_{3}$} \\
\hline $17-18$ & $0.31(0.10)$ & $0.01(0.01)$ & $0.31(0.09)$ \\
\hline $16-17$ & $0.39(0.12)$ & $0.02(0.02)$ & $0.35(0.11)$ \\
\hline $15-16$ & $0.54(0.15)$ & $0.04(0.04)$ & $0.49(0.16)$ \\
\hline $14-15$ & $0.53(0.15)$ & $0.07(0.05)$ & $0.53(0.18)$ \\
\hline \multicolumn{4}{|l|}{$\mathrm{CH}_{2} \mathrm{Br}_{2}$} \\
\hline $17-18$ & $0.79(0.08)$ & $0.02(0.04)$ & $0.78(0.07)$ \\
\hline $16-17$ & $0.83(0.07)$ & $0.04(0.04)$ & $0.81(0.07)$ \\
\hline $15-16$ & $0.90(0.07)$ & $0.07(0.06)$ & $0.87(0.10)$ \\
\hline \multirow[t]{2}{*}{$14-15$} & $0.91(0.08)$ & $0.12(0.09)$ & $0.89(0.12)$ \\
\hline & \multicolumn{2}{|c|}{$\begin{array}{l}\text { Boundary layer } \\
\text { fraction [\%] }\end{array}$} & $\begin{array}{l}\text { Background } \\
\text { fraction [\%] }\end{array}$ \\
\hline $17-18$ & \multicolumn{2}{|r|}{$1.9(2.3)$} & 98.1 \\
\hline $16-17$ & \multicolumn{2}{|r|}{$4.7(4.9)$} & 95.3 \\
\hline $15-16$ & \multicolumn{2}{|r|}{$9.8(7.9)$} & 90.2 \\
\hline $14-15$ & \multicolumn{2}{|c|}{$14.7(11.1)$} & 85.3 \\
\hline
\end{tabular}


Table 5. Contribution from the very short-lived bromocarbons: $\mathrm{CHBr}_{3}$ and $\mathrm{CH}_{2} \mathrm{Br}_{2}$ to the bromine in the TTL, as given by modelled estimates and AWAS observations for ATTREX 2014 and 2013. $\left[\mathrm{CHBr}_{3}\right]$ and $\left[\mathrm{CH}_{2} \mathrm{Br}_{2}\right]$ means are shown.

\begin{tabular}{|c|c|c|c|c|c|}
\hline Altitude [km] & $\begin{array}{r}{\left[\mathrm{CHBr}_{3}\right]} \\
{[\mathrm{ppt}]}\end{array}$ & $\begin{array}{r}{\left[\mathrm{CH}_{2} \mathrm{Br}_{2}\right]} \\
{[\mathrm{ppt}]}\end{array}$ & $\begin{array}{r}\mathrm{Br} \text { from } \mathrm{CHBr}_{3} \\
{[\mathrm{ppt}]}\end{array}$ & $\begin{array}{r}\mathrm{Br} \text { from } \mathrm{CH}_{2} \mathrm{Br}_{2} \\
{[\mathrm{ppt}]}\end{array}$ & $\begin{array}{r}\mathrm{Br}-\mathrm{VSL}_{\text {org }} \\
\text { [ppt] }\end{array}$ \\
\hline \multicolumn{6}{|l|}{ ATTREX 2014} \\
\hline \multicolumn{6}{|l|}{ NAME } \\
\hline $17-18$ & 0.32 & 0.73 & 0.96 & 1.46 & 2.42 \\
\hline $16-17$ & 0.40 & 0.78 & 1.20 & 1.56 & 2.76 \\
\hline $15-16$ & 0.50 & 0.80 & 1.50 & 1.60 & 3.10 \\
\hline $14-15$ & 0.55 & 0.84 & 1.65 & 1.68 & 3.33 \\
\hline \multicolumn{6}{|l|}{ AWAS } \\
\hline $17-18$ & 0.33 & 0.73 & 0.99 & 1.46 & 2.45 \\
\hline $16-17$ & 0.48 & 0.82 & 1.44 & 1.64 & 3.08 \\
\hline $15-16$ & 0.54 & 0.84 & 1.62 & 1.68 & 3.30 \\
\hline $14-15$ & 0.61 & 0.86 & 1.83 & 1.72 & 3.55 \\
\hline \multicolumn{6}{|l|}{ ATTREX 2013} \\
\hline \multicolumn{6}{|l|}{ NAME } \\
\hline $17-18$ & 0.31 & 0.78 & 0.93 & 1.56 & 2.49 \\
\hline 16-17 & 0.35 & 0.81 & 1.05 & 1.62 & 2.67 \\
\hline $15-16$ & 0.49 & 0.87 & 1.47 & 1.74 & 3.21 \\
\hline $14-15$ & 0.53 & 0.89 & 1.59 & 1.78 & 3.37 \\
\hline \multicolumn{6}{|l|}{ AWAS } \\
\hline $17-18$ & 0.31 & 0.79 & 0.93 & 1.58 & 2.51 \\
\hline 16-17 & 0.39 & 0.83 & 1.17 & 1.66 & 2.83 \\
\hline $15-16$ & 0.54 & 0.90 & 1.62 & 1.80 & 3.42 \\
\hline 14-15 & 0.53 & 0.91 & 1.59 & 1.82 & 3.41 \\
\hline
\end{tabular}

that originated below $1 \mathrm{~km}$ is calculated for each sample. A steep drop-off in this fraction is observed between 14-15 and 17-18 km. Low-level measurements of $\mathrm{CH}_{3} \mathrm{I}, \mathrm{CHBr}_{3}$ and $\mathrm{CH}_{2} \mathrm{Br}_{2}$ from the FAAM BAe-146 and the NCAR GV are used in conjunction with these trajectories and an assumed photochemical decay time to provide estimates of the amount of each gas reaching the TTL from below $1 \mathrm{~km}$. Comparison of these modelled estimates with the $\mathrm{CH}_{3}$ I measurements shows good agreement with the observations at the lower altitudes in the TTL values, with less good agreement at altitudes $>16 \mathrm{~km}$, though it should be noted that the amounts are very small here. The lifetime of $\mathrm{CH}_{3} \mathrm{I}$ is $3-5 \mathrm{~d}$ and thus there is a $>90 \%$ decay in the $12 \mathrm{~d}$ trajectories. The comparison between the modelled and measured $\mathrm{CH}_{3} \mathrm{I}$ thus indicates that the NAME convection scheme is realistic up to the lower TTL but less good at reproducing the small number of extreme convective events that penetrate to the upper TTL.

In order to perform similar calculations for the longerlived bromocarbons, an estimate of the background freetropospheric concentration is required. This is found by considering bromocarbon values in samples where there was only a small influence from the boundary layer, i.e. where very few NAME trajectories passed below $1 \mathrm{~km}$. This is possible in 2013 when the ATTREX flights were away from the region of strong convection but much harder in 2014 when (as planned!) the flights were heavily influenced by convection. By summing the boundary layer and background contributions, an estimate of the total bromocarbon mixing ratio is obtained.

The resulting modelled estimates are found to be in generally good agreement with the ATTREX measurements. In other words, a high degree of consistency is found between the low-altitude halocarbon measurements made on the BAe146 and GV and the high-altitude measurements made on the Global Hawk when they are connected using trajectories calculated by the NAME dispersion model with its updated convection scheme and driven by meteorological analyses with $25 \mathrm{~km}$ horizontal resolution. There are some indications of the modelled convection not always reaching quite high enough, but this is consistent with a known tendency of the Unified Model to underestimate the depth of the deepest convection in the tropics.

The resolved winds are likely to be well represented, at least partly because the wind data are analyses rather than 
forecast data. Hence, we expect the main errors in the modelling to arise from the representation of convection. Individual convective events are hard to model and can have significant errors. However, because the upper troposphere concentrations depend on a number of convective events and we are considering a range of flights and measurement locations, our conclusions on general behaviour should be robust. The consistency between the aircraft measurements and the NAME simulations supports this.

In the above, the boundary layer contribution arises from trajectories that visit the boundary layer within $12 \mathrm{~d}$ while the background contribution involves air that has been transported into the TTL from outside the boundary layer on timescales up to $12 \mathrm{~d}$. Sensitivity tests were performed in which the trajectories were followed for longer than $12 \mathrm{~d}$ : the effect was to re-allocate some of the air from the background category into the boundary layer contribution with no net change in the total.

The approach using NAME trajectories and boundary layer measurements produces $\mathrm{Br}^{-\mathrm{VSL}_{\text {org }}}$ estimates of $3.5 \pm$ $0.4(3.3 \pm 0.4) \mathrm{ppt}$ in the lower eastern (western) Pacific TTL $(14-15 \mathrm{~km})$ and $2.5 \pm 0.2(2.4 \pm 0.4) \mathrm{ppt}$ in the upper eastern (western) Pacific TTL (17-18 km). These lie within the range of the recent literature findings (Tegtmeier et al., 2012; Carpenter et al., 2014; Liang et al., 2014; Navarro et al., 2015; Butler et al., 2018; Wales et al. 2018). The validation with the ATTREX measurements provides confidence that a similar approach could be used for years when high-altitude measurements are not available, assuming that realistic estimates of the background tropospheric contributions can be obtained from either models or measurements.

Our study of boundary layer contribution of bromoform and dibromomethane into the TTL in the western Pacific, using a combined approach of NAME Lagrangian dispersion modelling and CAST, CONTRAST and ATTREX 2014 measurements, has successfully validated an updated convection scheme for use with the NAME trajectory model. The previous parameterization scheme was reasonable for convection at mid-latitudes but was far too weak to represent the stronger tropical convection. Comparison with the extensive $\mathrm{CH}_{3} \mathrm{I}$ measurements made in this campaign provides good support for its use in modelling transport in tropical convective systems (Meneguz et al., 2019).

This represents a considerable improvement on the earlier study by Ashfold et al. (2012), which used the old convection scheme and found reasonable agreement up to and including the level of maximum convective outflow but not above, when compared to measurements in the eastern Pacific from the NASA Costa Rica-Aura Validation Experiment (CR-AVE, 2006) and NASA Tropical Composition, Cloud and Climate Coupling (TC4, 2007) campaigns. The approach used by Ashfold et al. (2012) has been further extended so that VSL mixing ratios can be assigned to contributions from the boundary layer and from the "background" TTL.
Data availability. The $\mathrm{CH}_{3} \mathrm{I}, \mathrm{CHBr}_{3}$ and $\mathrm{CH}_{2} \mathrm{Br}_{2}$ AWAS data from the NASA ATTREX measurements are available online in the NASA ATTREX database (https://espoarchive. nasa.gov/archive/browse/attrex/id4, last access: 22 April 2017). The CAST measurements are stored on the British Atmospheric Data Centre, which is part of the Centre for Environmental Data archive at http://catalogue.ceda.ac.uk/uuid/ 565b6bb5a0535b438ad2fae4c852e1b3 (Natural Environment Research Council et al., 2014). The CONTRAST AWAS data are available through https://data.eol.ucar.edu/master_lists/generated/ contrast/ (last access: 30 January 2020). The NAME data are available from the corresponding author upon request. Please note that the full paper is accessible upon request, contact David Thomson from the UK Met Office, Atmospheric Dispersion and Air Quality Unit.

Author contributions. The main part of the analysis was conducted by MTF. ELA and MAN provided $\mathrm{CH}_{3} \mathrm{I}, \mathrm{CHBr}_{3}$ and $\mathrm{CH}_{2} \mathrm{Br}_{2}$ AWAS measurements from the ATTREX and CONTRAST research flights. SJA and $\mathrm{LJC}$ provided $\mathrm{CH}_{3} \mathrm{I}, \mathrm{CHBr}_{3}$ and $\mathrm{CH}_{2} \mathrm{Br}_{2}$ measurements from the CAST campaign. MJA designed initial scripts for NAME runs and products. EM and DT developed the model code for improved convection scheme. MTF and NRPH prepared the manuscript with contributions from all co-authors, NRPH also supervised this $\mathrm{PhD}$ work.

Competing interests. The authors declare that they have no conflict of interest.

Acknowledgements. The authors would like to thank our NASA ATTREX, NCAR CONTRAST and NERC CAST project partners and their technical teams. Michal T. Filus would like to thank Michelle Cain, Alex Archibald, Sarah Connors, Maria Russo and Paul Griffiths for their input on the NAME applications for flight planning and post-flight modelling. We acknowledge use of the NAME atmospheric dispersion model and associated NWP meteorological datasets made available to us by the UK Met Office.

Financial support. The research was funded through the UK Natural Environment Research Council CAST project (grant nos. NE/J006246/1 and NE/J00619X/1), and Michal T. Filus was supported by a NERC PhD studentship. Elliot L. Atlas received support from NASA (grant nos. NNX17AE43G, NNX13AH20G, and NNX10AOB3A).

Review statement. This paper was edited by Rolf Müller and reviewed by two anonymous referees. 


\section{References}

Anderson, D. C., Nicely, J. M., Salawitch, R. J., Canty, T. P., Dickerson, R. R., Hanisco, T. F., Wolfe, G. M., Apel, E. C., Atlas, E., Bannan, T., Bauguitte, S., Blake, N. J., Bresch, J. F., Campos, T. L., Carpenter, L. J., Cohen, M. D., Evans, M., Fernandez, R. P., Kahn, B. H., Kinnison, D. E., Hall, S. R., Harris, N. R. P., Hornbrook, R. S., Lamarque, J.-F., Le Breton, M., Lee, J. D., Percival, C., Pfister, L., Bradley Pierce, R., Riemer, D. D., Saiz-Lopez, A., Stunder, B. J. B., Thompson, A. M., Ullmann, K., Vaughan, A., and Weinheimer, A. J.: A pervasive role for biomass burning in tropical high ozone/low water structures, Nat. Commun., 7, 10267, https://doi.org/10.1038/ncomms10267, 2016.

Andrews, S. J., Jones, C. E., and Carpenter, L. J.: Aircraft measurements of very short-lived halocarbons over the tropical Atlantic Ocean, Geophys. Res. Lett., 40, 1005-1010, https://doi.org/10.1002/grl.50141, 2013.

Andrews, S. J., Carpenter, L. J., Apel, E. C., Atlas, E., Donets, V., Hopkins, J. R., Hornbrook, R. S., Lewis, A. C., Lidster, R. T., Lueb, R., Minaeian, J., Navarro, M., Punjabi, S., Riemer, D., and Schauffler, S.: A comparison of very short lived halocarbon (VSLS) and DMS aircraft measurements in the tropical west Pacific from CAST, ATTREX and CONTRAST, Atmos. Meas. Tech., 9, 5213-5225, https://doi.org/10.5194/amt-9-5213-2016, 2016.

Aschmann, J. and Sinnhuber, B.-M.: Contribution of very shortlived substances to stratospheric bromine loading: uncertainties and constraints, Atmos. Chem. Phys., 13, 1203-1219, https://doi.org/10.5194/acp-13-1203-2013, 2013.

Ashfold, M. J., Harris, N. R. P., Atlas, E. L., Manning, A. J., and Pyle, J. A.: Transport of short-lived species into the Tropical Tropopause Layer, Atmos. Chem. Phys., 12, 6309-6322, https://doi.org/10.5194/acp-12-6309-2012, 2012.

Ball, W. T., Alsing, J., Mortlock, D. J., Rozanov, E. V., Tummon, F., and Haigh, J. D.: Reconciling differences in stratospheric ozone composites, Atmos. Chem. Phys., 17, 1226912302, https://doi.org/10.5194/acp-17-12269-2017, 2017.

Ball, W. T., Alsing, J., Staehelin, J., Davis, S. M., Froidevaux, L., and Peter, T.: Stratospheric ozone trends for 1985-2018: sensitivity to recent large variability, Atmos. Chem. Phys., 19, 1273112748, https://doi.org/10.5194/acp-19-12731-2019, 2019.

Butler, R., Palmer, P. I., Feng, L., Andrews, S. J., Atlas, E. L., Carpenter, L. J., Donets, V., Harris, N. R. P., Montzka, S. A., Pan, L. L., Salawitch, R. J., and Schauffler, S. M.: Quantifying the vertical transport of $\mathrm{CHBr}_{3}$ and $\mathrm{CH}_{2} \mathrm{Br}_{2}$ over the western Pacific, Atmos. Chem. Phys., 18, 13135-13153, https://doi.org/10.5194/acp-18-13135-2018, 2018.

Carpenter, L. J., Sturges, W. T., Penkett, S. A., Liss, P. S., Alicke, B., Hebestreit, K., and Platt, U., Short-lived alkyl iodides and bromides at Mace Head, Ireland: Links to biogenic sources and halogen oxide production, J. Geophys. Res., 104, 1679-1689, https://doi.org/10.1029/98JD027461, 1999.

Carpenter, L. J., Archer, S. D., and Beale, R.: Ocean-atmosphere trace gas exchange, Chem. Soc. Rev., 41, 6473-6506, https://doi.org/10.1039/c2cs35121h, 2012.

Carpenter, L. J., Reimann, S., Burkholder, J. B., Clerbaux, C., Hall, B. D., Hossaini, R., Laube, J. C., and Yvon-Lewis, S. A.: Ozonedepleting substances (ODSs) and other gases of interest to the Montreal Protocol, Chap.1, in Scientific Assessment of Ozone Depletion, 2014; Global Ozone Research and Monitoring Project
- Report no. 55, World Meteorological Organisation, Geneva, Switzerland, 2014.

Chipperfield, M. P., Bekki, S., Dhomse, S., Harris, N. R. P., Hassler, B., Hossaini, R., Steinbrecht, W., Thiéblemont, R., and Weber, M.: Detecting recovery of the stratospheric ozone layer, Nature, 549, 211-218, https://doi.org/10.1038/nature23681, 2017.

Davies, T., Cullen, M. J. P., Malcolm, A. J., Mawson, M. H., Staniforth, A., White, A. A., and Wood, N.: A new dynamical core for the Met Office's global and regional modelling of the atmosphere, Q. J. Roy. Meteorol. Soc., 131, 1759-1782, https://doi.org/10.1256/qj.04.101, 2005.

Dessens, O., Zeng, G., Warwick, N., and Pyle, J.: Short-lived bromine compounds in the lower stratosphere; impact of climate change on ozone, Atmos. Sci. Lett., 10, 201-206, https://doi.org/10.1002/asl.236, 2009.

Engel, A., Rigby, M., Burkholder, J. B., Fernandez, R. P., Froidevaux, L., Hall, B. D., Hossaini, R., Saito, T., Vollmer, M. K., and Yao, B.: Update on Ozone-Depleting Substances (ODSs) and Other Gases of Interest to the Montreal Protocol, chap. 1, in: Scientific Assessment of Ozone Depletion: 2018, Global Ozone Research and Monitoring Project-Report No. 58, World Meteorological Organization, Geneva, Switzerland, 2018.

Fernandez, R. P., Salawitch, R. J., Kinnison, D. E., Lamarque, J.-F., and Saiz-Lopez, A.: Bromine partitioning in the tropical tropopause layer: implications for stratospheric injection, Atmos. Chem. Phys., 14, 13391-13410, https://doi.org/10.5194/acp-1413391-2014, 2014.

Fiehn, A., Quack, B., Hepach, H., Fuhlbrügge, S., Tegtmeier, S., Toohey, M., Atlas, E., and Krüger, K.: Delivery of halogenated very short-lived substances from the west Indian Ocean to the stratosphere during the Asian summer monsoon, Atmos. Chem. Phys., 17, 6723-6741, https://doi.org/10.5194/acp17-6723-2017, 2017.

Fueglistaler, S., Dessler, A. E., Dunkerton, T. J., Folkins, I., Fu, Q., and Mote, P. W.: Tropical tropopause layer, Rev. Geophys., 47, RG1004, https://doi.org/10.1029/2008RG000267, 2009.

Fuhlbrügge, S., Quack, B., Tegtmeier, S., Atlas, E., Hepach, H., Shi, Q., Raimund, S., and Krüger, K.: The contribution of oceanic halocarbons to marine and free tropospheric air over the tropical West Pacific, Atmos. Chem. Phys., 16, 7569-7585, https://doi.org/10.5194/acp-16-7569-2016, 2016.

Harris, N. R. P., Hassler, B., Tummon, F., Bodeker, G. E., Hubert, D., Petropavlovskikh, I., Steinbrecht, W., Anderson, J., Bhartia, P. K., Boone, C. D., Bourassa, A., Davis, S. M., Degenstein, D., Delcloo, A., Frith, S. M., Froidevaux, L., Godin-Beekmann, S., Jones, N., Kurylo, M. J., Kyrölä, E., Laine, M., Leblanc, S. T., Lambert, J.-C., Liley, B., Mahieu, E., Maycock, A., de Mazière, M., Parrish, A., Querel, R., Rosenlof, K. H., Roth, C., Sioris, C., Staehelin, J., Stolarski, R. S., Stübi, R., Tamminen, J., Vigouroux, C., Walker, K. A., Wang, H. J., Wild, J., and Zawodny, J. M.: Past changes in the vertical distribution of ozone - Part 3: Analysis and interpretation of trends, Atmos. Chem. Phys., 15, 9965-9982, https://doi.org/10.5194/acp15-9965-2015, 2015.

Harris, N. R. P., Carpenter, L. J., Lee, J. D., Vaughan, G., Filus, M. T., Jones, R. L., OuYang, B., Pyle, J. A., Robinson, A. D., Andrews, S. J., Lewis, A. C., Minaeian, J., Vaughan, A., Dorsey, J. R., Gallagher, M. W., Le Breton, M., Newton, R., Percival, C. J., Ricketts, H. M. A., Bauguitte, S. J.-B., Nott, G. J., 
Wellpott, A., Ashfold, M. J., Flemming, J., Butler, R., Palmer, P. I., Kaye, P. H., Stopford, C., Chemel, C., Boesch, H., Humpage, N., Vick, A., MacKenzie, A. R., Hyde, R., Angelov, P., Meneguz, E., and Manning, A. J.: 2017: Coordinated Airborne Studies in the Tropics (CAST), B. Am. Meteorol. Soc., 98, 145-162, https://doi.org/10.1175/BAMS-D-14-00290.1, 2017.

Hepach, H., Quack, B., Raimund, S., Fischer, T., Atlas, E. L., and Bracher, A.: Halocarbon emissions and sources in the equatorial Atlantic Cold Tongue, Biogeosciences, 12, 6369-6387, https://doi.org/10.5194/bg-12-6369-2015, 2015.

Hosking, J. S., Russo, M. R., Braesicke, P., and Pyle, J. A.: Tropical convective transport and the Walker circulation, Atmos. Chem. Phys., 12, 9791-9797, https://doi.org/10.5194/acp12-9791-2012, 2012.

Hossaini, R., Patra, P. K., Leeson, A. A., Krysztofiak, G., Abraham, N. L., Andrews, S. J., Archibald, A. T., Aschmann, J., Atlas, E. L., Belikov, D. A., Bönisch, H., Carpenter, L. J., Dhomse, S., Dorf, M., Engel, A., Feng, W., Fuhlbrügge, S., Griffiths, P. T., Harris, N. R. P., Hommel, R., Keber, T., Krüger, K., Lennartz, S. T., Maksyutov, S., Mantle, H., Mills, G. P., Miller, B., Montzka, S. A., Moore, F., Navarro, M. A., Oram, D. E., Pfeilsticker, K., Pyle, J. A., Quack, B., Robinson, A. D., Saikawa, E., Saiz-Lopez, A., Sala, S., Sinnhuber, B.-M., Taguchi, S., Tegtmeier, S., Lidster, R. T., Wilson, C., and Ziska, F.: A multi-model intercomparison of halogenated very shortlived substances (TransCom-VSLS): linking oceanic emissions and tropospheric transport for a reconciled estimate of the stratospheric source gas injection of bromine, Atmos. Chem. Phys., 16, 9163-9187, https://doi.org/10.5194/acp-16-9163-2016, 2016.

Hossaini, R., Chipperfield, M., Montzka, S. A., Leeson, A. A., Dhomse, S. S., and Pyle, J. A.: The increasing threat to stratospheric ozone from dichloromethane, Nat. Commun., 8, 15962, https://doi.org/10.1038/ncomms15962, 2017.

Jensen, E. J., Pfister, L., Jordan, D. E., Bui, T. V., Ueyama, R., Singh, H. B., Thornberry, T. D., Rollins, A. W., Gao, R., Fahey, D. W., Rosenlof, K. H., Elkins, J. W., Diskin, G. S., DiGangi, J. P., Lawson, R. P., Woods, S., Atlas, E. L., Navarro Rodriguez, M. A., Wofsy, S. C., Pittman, J., Bardeen, C. G., Toon, O. B., Kindel, B. C., Newman, P. A., McGill, M. J., Hlavka, D. L., Lait, L. R., Schoeberl, M. R., Bergman, J. W., Selkirk, H. B., Alexander, M. J., Kim, J.-E., Lim, B. H., Stutz, J., and Pfeilsticker, K.: The NASA Airborne Tropical Tropopause Experiment: High-Altitude Aircraft Measurements in the Tropical Western Pacific, B. Am. Meteorol. Soc., 98, 129-143, https://doi.org/10.1175/BAMS-D-14-00263.1, 2017.

Jones, A., Thomson, D., Hort, M., and Devenish, B.: The U.K. Met Office's Next-Generation Atmospheric Dispersion Model, NAME III Air Pollution Modeling and Its Application XVII, Springer US, 580-589, https://doi.org/10.1007/9780-387-68854-1_62, 2007.

Krzysztofiak, G., Catoire, V., Hamer, P. D., Marécal, V., Robert, C., Engel, A., Bönisch, H., Grossman, K., Quack, B., Atlas, E., and Pfeilsticker, K.: Evidence of convective transport in tropical West Pacific region during SHIVA experiment, Atmos. Sci. Lett., 19, 1-7, https://doi.org/10.1002/asl.798, 2018.

Liang, Q., Stolarski, R. S., Kawa, S. R., Nielsen, J. E., Douglass, A. R., Rodriguez, J. M., Blake, D. R., Atlas, E. L., and Ott, L. E.: Finding the missing stratospheric $\mathrm{Br}_{\mathrm{y}}$ : a global modeling study of $\mathrm{CHBr}_{3}$ and $\mathrm{CH}_{2} \mathrm{Br}_{2}$, Atmos. Chem. Phys., 10, 2269-2286, https://doi.org/10.5194/acp-10-2269-2010, 2010.

Liang, Q., Atlas, E., Blake, D., Dorf, M., Pfeilsticker, K., and Schauffler, S.: Convective transport of very short lived bromocarbons to the stratosphere, Atmos. Chem. Phys., 14, 5781-5792, https://doi.org/10.5194/acp-14-5781-2014, 2014.

Lovelock, J. E.: Natural halocarbons in the air and in the sea, Nature, 256, 193-194, https://doi.org/10.1038/256193a0, 1975.

Meneguz, E. and Thomson, D. J.: Towards a new scheme for parametrization of deep convection in NAME III, Int. J. Environ. Pollut., 54, 128-136, https://doi.org/10.1504/IJEP.2014.065113, 2014.

Meneguz, E., Filus, M., Selvaratnam, V., Thomson, D. J., Harris, N. P. R., Witham, C. S., Navarro, M. A., and Atlas, E. L.: Improved parametrization scheme to represent tropospheric moist convection in the atmospheric dispersion model NAME, Forecasting Research Technical Report 639, Met Office, United Kingdom, 2019.

Moore, R. M., Geen, C. E., and Tait, V. K.: Determination of Henry Law constants for a suite of naturally-occurring halo- genated methanes in seawater, Chemosphere, 30, 1183-1191, 1995.

Natural Environment Research Council, Braesicke, P., Harris, N., Pyle, J. A., Robinson, A., and Vaughan, G.: Co-ordinated Airborne Studies in the Tropics (CAST): In-situ airborne, ozonesonde and ground based and atmospheric chemistry measurements, NCAS British Atmospheric Data Centre, http://catalogue.ceda.ac.uk/uuid/ 565b6bb5a0535b438ad2fae4c852e1b3 (last access: January 2020), 2014.

Navarro, M. A., Atlas, E. A., Saiz-Lopez, A., Rodriguez-Lloveras, X., Kinnison, D. E., Lamarque, J.-F., Tilmes, S., Filus, M., Harris, N. R. P., Meneguz, E., Ashfold, M. J., Manning, A. J., Cuevas, C. A., Schauffler, S. M., and Donets, V.: Airborne measurements of organic bromine compounds in the Pacific tropical tropopause layer, P. Natl. Acad. Sci. USA, 112, 13789-13793, https://doi.org/10.1073/pnas.1511463112, 2015.

Navarro, M. A., Saiz-Lopez, A., Cuevas, C. A., Fernandez, R. P., Atlas, E., Rodriguez-Lloveras, X., Kinnison, D., Lamarque, J.F., Tilmes, S., Thornberry, T., Rollins, A., Elkins, J. W., Hintsa, E. J., and Moore, F. L.: Modeling the inorganic bromine partitioning in the tropical tropopause layer over the eastern and western Pacific Ocean, Atmos. Chem. Phys., 17, 9917-9930, https://doi.org/10.5194/acp-17-9917-2017, 2017.

Newton, R., Vaughan, G., Hintsa, E., Filus, M. T., Pan, L. L., Honomichl, S., Atlas, E., Andrews, S. J., and Carpenter, L. J.: Observations of ozone-poor air in the tropical tropopause layer, Atmos. Chem. Phys., 18, 5157-5171, https://doi.org/10.5194/acp18-5157-2018, 2018.

Oram, D. E. and Penkett, S. A.: Observations in eastern England of elevated methyl iodide concentrations in air of Atlantic origin, Atmos. Environ., 28, 1159-1174, https://doi.org/10.1016/13522310(94)90293-3, 1994.

Oram, D. E., Ashfold, M. J., Laube, J. C., Gooch, L. J., Humphrey, S., Sturges, W. T., Leedham-Elvidge, E., Forster, G. L., Harris, N. R. P., Mead, M. I., Samah, A. A., Phang, S. M., Ou-Yang, C.-F., Lin, N.-H., Wang, J.-L., Baker, A. K., Brenninkmeijer, C. A. M., and Sherry, D.: A growing threat to the ozone layer from short-lived anthropogenic chlorocarbons, Atmos. Chem. 
Phys., 17, 11929-11941, https://doi.org/10.5194/acp-17-119292017, 2017.

Pan, L. L., Atlas, E. L., Salawitch, R. J., Honomichl, S. B., Bresch, J. F., Randel, W. J., Apel, E. C., Hornbrook, R. S., Weinheimer, A. J., Anderson, D. C., Andrews, S. J., Baidar, S., Beaton, S. P., Campos, T. L., Carpenter, L. J., Chen, D., Dix, B., Donets, V., Hall, S. R., Hanisco, T. F., Homeyer, C. R., Huey, L. G., Jensen, J. B., Kaser, L., Kinnison, D. E., Koenig, T. K., Lamarque, J., Liu, C., Luo, J., Luo, Z. J., Montzka, D. D., Nicely, J. M., Pierce, R. B., Riemer, D. D., Robinson, T., Romashkin, P., Saiz-Lopez, A., Schauffler, S., Shieh, O., Stell, M. H., Ullmann, K., Vaughan, G., Volkamer, R., and Wolfe, G.: The Convective Transport of Active Species in the Tropics (CONTRAST) Experiment, B. Am. Meteorol. Soc., 98, 106-128, https://doi.org/10.1175/BAMS-D14-00272.1, 2017.

Park, S., Atlas, E. L., Jiménez, R., Daube, B. C., Gottlieb, E. W., Nan, J., Jones, D. B. A., Pfister, L., Conway, T. J., Bui, T. P., Gao, R.-S., and Wofsy, S. C.: Vertical transport rates and concentrations of $\mathrm{OH}$ and $\mathrm{Cl}$ radicals in the Tropical Tropopause Layer from observations of $\mathrm{CO}_{2}$ and halocarbons: implications for distributions of long- and short-lived chemical species, Atmos. Chem. Phys., 10, 6669-6684, https://doi.org/10.5194/acp10-6669-2010, 2010.

Pfeilsticker, K., Sturges, W. T., Bosch, H., Camy-Peyret, C., Chipperfield, M. P., Engel, A., Fitzenberger, R., Muller, M., Payan, S., and Sinnhuber, B.-M.: Lower stratospheric organic and inorganic bromine budget for the arctic winter 1998/1999, Geophys. Res. Lett., 27, 3305-3308, https://doi.org/10.1029/2000GL011650, 2000.

Pyle, J. A., Ashfold, M. J., Harris, N. R. P., Robinson, A. D., Warwick, N. J., Carver, G. D., Gostlow, B., O’Brien, L. M., Manning, A. J., Phang, S. M., Yong, S. E., Leong, K. P., Ung, E. H., and Ong, S.: Bromoform in the tropical boundary layer of the Maritime Continent during OP3, Atmos. Chem. Phys., 11, 529-542, https://doi.org/10.5194/acp-11-529-2011, 2011.

Russo, M. R., Marécal, V., Hoyle, C. R., Arteta, J., Chemel, C., Chipperfield, M. P., Dessens, O., Feng, W., Hosking, J. S., Telford, P. J., Wild, O., Yang, X., and Pyle, J. A.: Representation of tropical deep convection in atmospheric models - Part 1: Meteorology and comparison with satellite observations, Atmos. Chem. Phys., 11, 2765-2786, https://doi.org/10.5194/acp11-2765-2011, 2011.

Russo, M. R., Ashfold, M. J., Harris, N. R. P., and Pyle, J. A.: On the emissions and transport of bromoform: sensitivity to model resolution and emission location, Atmos. Chem. Phys., 15, 1403114040, https://doi.org/10.5194/acp-15-14031-2015, 2015.

Saiz-Lopez, A., Fernandez, R. P., Ordóñez, C., Kinnison, D. E., Gómez Martín, J. C., Lamarque, J.-F., and Tilmes, S.: Iodine chemistry in the troposphere and its effect on ozone, Atmos. Chem. Phys., 14, 13119-13143, https://doi.org/10.5194/acp-1413119-2014, 2014.

Sala, S., Bönisch, H., Keber, T., Oram, D. E., Mills, G., and Engel, A.: Deriving an atmospheric budget of total organic bromine using airborne in situ measurements from the western Pacific area during SHIVA, Atmos. Chem. Phys., 14, 6903-6923, https://doi.org/10.5194/acp-14-6903-2014, 2014.

Schauffler, S. M., Atlas, E. L., Flocke, F., Lueb, R. A., Stroud, V., and Travnicek, W.: Measurements of bromine containing organic compounds at the tropical tropopause, Geophys. Res. Lett., 25, 317-320, https://doi.org/10.1029/98GL00040, 1998.

Schofield, R., Fueglistaler, S., Wohltmann, I., and Rex, M.: Sensitivity of stratospheric Bry to uncertainties in very short lived substance emissions and atmospheric transport, Atmos. Chem. Phys., 11, 1379-1392, https://doi.org/10.5194/acp-111379-2011, 2011.

Steinbrecht, W., Froidevaux, L., Fuller, R., Wang, R., Anderson, J., Roth, C., Bourassa, A., Degenstein, D., Damadeo, R., Zawodny, J., Frith, S., McPeters, R., Bhartia, P., Wild, J., Long, C., Davis, S., Rosenlof, K., Sofieva, V., Walker, K., Rahpoe, N., Rozanov, A., Weber, M., Laeng, A., von Clarmann, T., Stiller, G., Kramarova, N., Godin-Beekmann, S., Leblanc, T., Querel, R., Swart, D., Boyd, I., Hocke, K., Kämpfer, N., Maillard Barras, E., Moreira, L., Nedoluha, G., Vigouroux, C., Blumenstock, T., Schneider, M., García, O., Jones, N., Mahieu, E., Smale, D., Kotkamp, M., Robinson, J., Petropavlovskikh, I., Harris, N., Hassler, B., Hubert, D., and Tummon, F.: An update on ozone profile trends for the period 2000 to 2016, Atmos. Chem. Phys., 17, 1067510690, https://doi.org/10.5194/acp-17-10675-2017, 2017.

Tegtmeier, S., Krüger, K., Quack, B., Atlas, E. L., Pisso, I., Stohl, A., and Yang, X.: Emission and transport of bromocarbons: from the West Pacific ocean into the stratosphere, Atmos. Chem. Phys., 12, 10633-10648, https://doi.org/10.5194/acp-12-106332012, 2012.

Tegtmeier, S., Krüger, K., Quack, B., Atlas, E., Blake, D. R., Boenisch, H., Engel, A., Hepach, H., Hossaini, R., Navarro, M. A., Raimund, S., Sala, S., Shi, Q., and Ziska, F.: The contribution of oceanic methyl iodide to stratospheric iodine, Atmos. Chem. Phys., 13, 11869-11886, https://doi.org/10.5194/acp-13-118692013, 2013.

Tegtmeier, S., Ziska, F., Pisso, I., Quack, B., Velders, G. J. M., Yang, X., and Krüger, K.: Oceanic bromoform emissions weighted by their ozone depletion potential, Atmos. Chem. Phys., 15, 1364713663, https://doi.org/10.5194/acp-15-13647-2015, 2015.

Vogt, R., Sander, R., von Glasow, R., and Crutzen, P. J.: Iodine chemistry and its role in halogen activation and ozone loss in the marine boundary layer: a model study, J. Atmos. Chem., 32, 375-395, https://doi.org/10.1023/A:1006179901037, 1999.

Wales, P. A., Salawitch, R. J., Nicely, J. M., Anderson, D. C., Canty, T. P., Baidar, S., Dix, B., Koenig, T. K., Volkamer, R., Chen, D., Huey, L. G., Tanner, D. J., Cuevas, C. A., Fernandez, R. P., Kinnison, D. E., Lamarque, J.-F., Saiz-Lopez, A., Atlas, E. L., Hall, S. R., Navarro, M. A., Pan, L. L., Schauffler, S. M., Stell, M., Tilmes, S., Ullmann, K., Weinheimer, A. J., Akiyoshi, H., Chipperfield, M., Deushi, M., Dhomse, S. S., Feng, W., Graf, P., Hossaini, R., Jockel, P., Mancini, E., Michou, M., Morgenstern, O., Oman, L. D., Pitari, G., Plummer, D .A., Revell, L. E., Rozanov, E., Saint-Martin, D., Schofield, R., Stenke, A., Stone, K. A., Visioni, D., Yamashita, Y., and Zeng, G.: Stratospheric injection of brominated very short-lived substances: aircraft observations in the Western Pacific and representation in global models, J. Geophys. Res.-Atmos., 123, 56905719, https://doi.org/10.1029/2017JD027978, 2018.

Walters, D., Baran, A. J., Boutle, I., Brooks, M., Earnshaw, P., Edwards, J., Furtado, K., Hill, P., Lock, A., Manners, J., Morcrette, C., Mulcahy, J., Sanchez, C., Smith, C., Stratton, R., Tennant, W., Tomassini, L., Van Weverberg, K., Vosper, S., Willett, M., Browse, J., Bushell, A., Carslaw, K., Dalvi, M., Essery, R., Ged- 
ney, N., Hardiman, S., Johnson, B., Johnson, C., Jones, A., Jones, C., Mann, G., Milton, S., Rumbold, H., Sellar, A., Ujiie, M., Whitall, M., Williams, K., and Zerroukat, M.: The Met Office Unified Model Global Atmosphere 7.0/7.1 and JULES Global Land 7.0 configurations, Geosci. Model Dev., 12, 1909-1963, https://doi.org/10.5194/gmd-12-1909-2019, 2019.

Wang, S., Schmidt, J. A., Baidar, S., Coburn, S., Dix, B., Koenig, T. K., Apel, E., Bowdalo, D., Campos, T. L., Eloranta, E., Evans, M. J., DiGangi, J. P., Zondlo, M. A., Gao, R. S., Haggerty, J. A., Hall, S. R., Hornbrook, R. S., Jacob, D., Morley, B., Pierce, B., Reeves, M., Romashkin, P., Ter Schure A., and Volkamer, R.: Active and widespread halogen chemistry in the tropical and subtropical free troposphere, P. Natl. Acad. Sci. USA, 112, 92819286, https://doi.org/10.1073/pnas.1505142112, 2015.
Yang, G. P., Yang, B., and Lu, X. L.: Spatio-temporal variations of sea surface halocarbon concentrations and fluxes from southern Yellow Sea, Biogeochemistry, 121, 369-388, https://doi.org/10.1007/s10533-014-0007-x, 2014. 